\title{
CYCLING and SOCIAL INCLUSION
}

This report describes an action research project, supported by the Ashden Trust, that investigated and generated action on small-scale local cycling projects in the UK, with a focus on exploring the links between such projects and social inclusion

Jake Elster

November 2000 


\section{Centre for Analysis of Social Exclusion}

The ESRC Research Centre for Analysis of Social Exclusion (CASE) was established in October 1997 with funding from the Economic and Social Research Council. It is located within the Suntory and Toyota International Centres for Economics and Related Disciplines (STICERD) at the London School of Economics and Political Science, and benefits from support from STICERD. It is directed by Howard Glennerster, John Hills, Kathleen Kiernan, Julian Le Grand, Anne Power and Carol Propper.

Our Discussion Paper series is available free of charge. We also produce summaries of our research in CASEbriefs, and reports from various conferences and activities in CASEreports. To subscribe to the CASEpaper series, or for further information on the work of the Centre and our seminar series, please contact the Centre Administrator, Jane Dickson, on:

$\begin{array}{ll}\text { Telephone: } & \text { UK+20 } 79556679 \\ \text { Fax: } & \text { UK+20 } 79556951 \\ \text { Email: } & \text { j.dickson@lse.ac.uk } \\ \text { Web site: } & \text { http://sticerd.lse.ac.uk/Case }\end{array}$

(C) Jake Elster

All rights reserved. Short sections of text, not to exceed two paragraphs, may be quoted without explicit permission provided that full credit, including (c) notice, is given to the source. 


\section{SUMMARY}

\section{CONTENTS}

\section{PART I}

1. Introduction 1

2. Method 4

3. Results - Stage 1: Existing action 6

The cycling projects database - a national Picture of existing action 6

$\begin{array}{ll}\text { London wide picture of existing cycling activity } & 11\end{array}$

4. Results - Stage 2: Taking a lead in developing new action

Potential pilot project ideas

The pilot projects

5. Results - Stage 3: Supporting others to take

Action through the Bike up your life

Programme

Response to the Bike up your life programme

Providing support-Basic support and the

Intensive support Pedal Power programme

6. Conclusions

What benefits can small scale cycling projects

Deliver?

If small-scale cycling projects are worthwhile, how can their

Adoption and establishment best be supported?

Overview

PART II

The Pilot project case studies

The Pedal Power case studies

\section{APPENDICES}

Appendix 1 - Detailed range of project types

From the cycling projects database

Appendix 2 - Detailed example of Basic support provided to One group

Appendix 3 - Promotion and advertising of Bike up your Life $\quad 74$

Appendix 4 - Data collection and recording $\quad 75$

$\begin{array}{ll}\text { Appendix 5 - Obtaining copies of the full database } & 76\end{array}$ 


\section{List of tables}

\begin{tabular}{|c|c|c|}
\hline Number & Title & Page \\
\hline 3.1 & $\begin{array}{l}\text { Types of projects contained on the national cycling } \\
\text { projects database }\end{array}$ & 8 \\
\hline 3.2 & $\begin{array}{l}\text { Geographical spread of cycling projects on the Cycling } \\
\text { projects database }\end{array}$ & 8 \\
\hline 3.3 & $\begin{array}{l}\text { Type of organisation running cycling projects from the } \\
\text { Cycling projects database }\end{array}$ & 9 \\
\hline 3.4 & $\begin{array}{l}\text { Set up and annual running costs reported by cycling } \\
\text { projects on the Cycling projects database }\end{array}$ & 9 \\
\hline 3.5 & $\begin{array}{l}\text { Categories of successful outcomes reported by cycling } \\
\text { projects from the Cycling projects database }\end{array}$ & 10 \\
\hline 3.6 & $\begin{array}{l}\text { Activities around cycling carried out by the London } \\
\text { boroughs }\end{array}$ & 12 \\
\hline 3.7 & $\begin{array}{l}\text { Activities around cycling carried out by non-local } \\
\text { authority groups / organisations in all London boroughs }\end{array}$ & 12 \\
\hline 4.1 & $\begin{array}{l}\text { Outcomes and outputs that the pilot projects reported, } \\
\text { showing how they illustrate in more detail the most often } \\
\text { reported outcomes from the database projects }\end{array}$ & 16 \\
\hline 4.2 & $\begin{array}{l}\text { Range of ways in which we were involved in the } \\
\text { development of the pilot projects and how this impacted } \\
\text { on them }\end{array}$ & 18 \\
\hline 5.1 & Geographical spread in responses to Bike up your life & 22 \\
\hline 5.2 & Type of organisation applying for Bike up your life support & 24 \\
\hline 5.3 & $\begin{array}{l}\text { What the groups applying to Bike up your life were } \\
\text { proposing to do }\end{array}$ & 25 \\
\hline 5.4 & $\begin{array}{l}\text { Type of help that groups applying to Bike up your life said } \\
\text { they needed for setting up projects }\end{array}$ & 26 \\
\hline 5.5 & $\begin{array}{l}\text { What the groups applying to Bike up your life said they } \\
\text { wanted to achieve by setting up a cycling project - i.e. } \\
\text { their stated aims }\end{array}$ & 27 \\
\hline
\end{tabular}




\begin{tabular}{|c|c|c|}
\hline 5.6 & $\begin{array}{l}\text { Reasons given by non-applicant groups for their initial } \\
\text { enquiry about Bike up your life, and for not subsequently } \\
\text { applying for support }\end{array}$ & 28 \\
\hline 5.7 & $\begin{array}{l}\text { Basic support we provided to groups through Bike up your } \\
\text { life }\end{array}$ & 30 \\
\hline 5.8 & $\begin{array}{l}\text { Way in which groups reported that our Basic support } \\
\text { contributed to and/or impacted on their cycling work }\end{array}$ & 31 \\
\hline 5.9 & $\begin{array}{l}\text { Existing, ongoing and new cycling activity in } 14 \text { groups } \\
\text { after having received Basic support }\end{array}$ & 32 \\
\hline & Background information for the Pedal Power groups & \\
\hline 5.10 & Reported and observed positive outcomes from Pedal & 34 \\
\hline 5.11 & Power projects & 37 \\
\hline 5.12 & $\begin{array}{l}\text { Range of ways in which our support impacted on the Pedal } \\
\text { Power groups and contributed to the positive outcomes } \\
\text { seen }\end{array}$ & 37 \\
\hline 5.13 & $\begin{array}{l}\text { Aim and content of the Pedal Power residential training } \\
\text { courses }\end{array}$ & 38 \\
\hline 5.14 & $\begin{array}{l}\text { Range of support provided by the Pedal Power training } \\
\text { courses, as reported by participants }\end{array}$ & 39 \\
\hline 5.15 & $\begin{array}{l}\text { Range of things that participants said they would do } \\
\text { differently as a result of the Pedal Power training courses }\end{array}$ & 40 \\
\hline 6.1 & $\begin{array}{l}\text { How the different approaches we took to supporting } \\
\text { project development match the range of needs } \\
\text { encountered }\end{array}$ & 48 \\
\hline 6.2 & $\begin{array}{l}\text { Compares and contrasts the different approaches to } \\
\text { supporting cycling project establishment }\end{array}$ & 47 \\
\hline 6.3 & $\begin{array}{l}\text { Scope of the different approaches we took to supporting } \\
\text { the development of cycling projects }\end{array}$ & 49 \\
\hline 6.4 & $\begin{array}{l}\text { How different approaches to support impacted on projects } \\
\text { they were trying to help }\end{array}$ & 50 \\
\hline
\end{tabular}




\section{Summary}

This report describes an action research project that investigated and generated action on small-scale local cycling projects in the UK, with a focus on exploring the links between such projects and social inclusion.

- Cycling is relevant to the issue of sustainable transport, as a non-polluting alternative to car use. In other European countries cycling represents a considerable share of journeys but this is not being achieved in the U.K.

- LSE Housing carried out this project as part of the Centre for Analysis of Social Exclusion with the aims of increasing action around cycling in low-income areas and of investigating the links between cycling and social inclusion. We wanted to look at how cycling projects can help contribute to social inclusion, and how the potential social inclusion links can help to engage the interest of communities in cycling.

- This work was an action-research project. The core approach involved instigating and supporting action on local small-scale cycling projects, with research being carried alongside the action.

- A national overview of 73 cycling project found that there is a wide range of existing projects spread over the UK including, a cycle circus, cycle pools and BMX tracks. Approximately half of the projects were low-cost and they were most frequently led by the public sector. Projects led by community organisations were very poorly represented.

- The projects reported a wide range of successful outcomes, including providing new services and facilities, promoting and increasing cycling, providing training and skills, and successful financial outcomes. Nearly twice as many groups had basic non-cycling related aims such as crime diversion as had directly cycling related aims.

- Work on cycling in the majority of London local authorities was confined to infrastructure and facility provision, for example cycle lanes and cycle parking, training and promotion, and planning work. Very few London local authorities were carrying out local project work involving communities. Community, or non-local authority, led small-scale cycling projects were reported in 8 boroughs.

- In our first stage of action work we took a lead in establishing four pilot cycling projects in two London boroughs. The projects achieved a wide range of positive outcomes, including engaging 'at risk' young people in challenging activities, providing new services, local people being employed and young people receiving training.

- We had wide ranging involvement in, and impact on, the pilot projects, from helping bring the projects into existence, through involving partners and 
developing project plans, to raising funding and on-going involvement in their practical setting-up and running.

- In our second stage of action work we provided support to help community groups develop their own cycling projects. The response to the programme of support demonstrated a significant level of interest in cycling projects at the community level. Youth, local authority and voluntary services are also keen to get involved. Again, non-cycling related aims were an important part of the motivation of the groups wanting to develop cycling projects.

- We provided basic support to 26 groups, including general and specific information, contacts and specific advice. Our support had an impact on over half of the 14 groups that provided follow up information in ways such as directing thinking, giving ideas and contacts, giving confidence and legitimacy, and helping them secure funding.

- We provided intensive support to eight youth groups in low-income areas, including, information and advice, training, small grants, and ongoing 'handholding' support. Four of the groups developed new cycling projects and two developed their existing cycling work further.

- Small-scale cycling projects represent a way of engaging a much wider audience with cycling than the conventional approach of promoting cycling as transport. They are relevant to a range of high priority needs and priorities in many communities, for example crime diversion, activities for young people, and training. They can also be an effective tool for contributing to community development and social inclusion needs.

- Small-scale cycling projects can play a part in creating a supportive culture for cycling and can impact on increasing cycling directly. They offer an important approach to promoting cycling to policy makers.

- Local communities can need a wide range of different types of support to help them set up cycling projects, from basic information and advice, through training and funding, to consultancy help with specific tasks and ongoing intensive support.

- We developed three different approaches to providing this support and discuss their relative advantages and disadvantages. Together, these approaches cover a range of needs that communities encounter when establishing live cycling projects. The approaches are:

- Taking a lead in setting up projects

- Providing basic support to others who are setting up projects

- Providing intensive support to others setting up projects

A significant expansion of cycling project activity in the UK has the potential to contribute to several Government and non-government agendas, such as sustainable transport and the Social inclusion Unit's work on neighbourhood renewal. 


\section{PART I}

\section{INTRODUCTION}

\section{SCOPE AND PURPOSE}

This report describes the work that LSE Housing has been doing, as part of the Centre for Analysis of Social Exclusion, on small-scale community cycling initiatives for 2 years starting in June 1998. This work was co-initiated and supported by the Ashden Trust.

It sets this work in its wider context and describes the rationale behind our approach. It lays out the methodology we have used and reports the results we have obtained. Finally it explores the conclusions that can be drawn from these results and their implications.

\section{BACKGROUND}

The following issues are important in informing this work:

Sustainable transport - Transport plays a vital role in our society. In the UK the private car has come to dominate transport. This has brought problems that seriously counter the benefits of car use at a national scale, such as congestion, carbon dioxide emissions, local air pollution and the increasing vulnerability of non-car drivers, for example the young and elderly. At the same time investment in public transport has been sidelined until recently. Nearly a third of households in Britain do not have a car but still suffer the negative effects of cars, often disproportionately. For example many low-income housing estates where car ownership is extremely low are situated on main roads.

Cycling - Cycling is an ecologically sustainable form of transport. It does not produce pollution and congestion and offers an alternative to car use for many short journeys. As such it has the potential to play an important part in a new integrated, sustainable, transport system:

- $\quad 73 \%$ of journeys are under 5 miles, and $47 \%$ under 2 miles, distances that are appropriate for cycling.

- European countries that are comparable to the UK in terms of geography, climate and economy have achieved significant modal shares (proportion of all trips made by all transport modes) for cycling (Sweden 10\%, Germany 11\%, and Denmark 18\%. In Holland around $65 \%$ of children go to school by bike ${ }^{1}$.

- More people own cycles than cars in the UK and cycle purchase and leisure cycling are growing.

- The UK government produced a National Cycling Strategy in 1996 with targets to double cycle trips (from 1996 figures) by the end of 2002 and quadruple them by 2012.

However in the UK this potential is not being realised. Cycling fell dramatically from the 1950 s to hold a low modal share of $2 \%$ in 1996 . Only $2 \%$ of children travel to school by bike $^{2}$. A number of different factors contribute to this shortfall, including:

\footnotetext{
${ }^{1}$ Figures from The National Cycling Strategy, DETR (1996)

${ }^{2}$ The National Cycling Strategy, DETR (1996)
} 
- Many young people are restricted from cycling on roads by their parents / carers, or give up cycling to school mainly because it is too dangerous.

- The question of desirability drastically impacts on this potential. People don't want to cycle for all sorts of reasons, such as: weather; effort; terrain; traffic danger; fashion; status; culture. Many people do not see cycling as a positive thing but rather as a 'poor man's alternative', while a car is something desirable to be aspired to.

- Despite the National Cycling Strategy cycling is still regarded as a marginal activity by many politicians and as such is in danger of remaining marginal in policy terms.

- Cycling as transport or for leisure or fitness has limited relevance, or is not convenient or easy, for a wide range of people including the elderly, people with young children, and people who are unfit.

Community development - Local people and communities getting involved in building solutions to the problems they face is one effective part of the approach to tackling the problems of low-income areas. In doing so they can improve conditions, and at the same time build their capacity to keep responding to problems and improving their lives. Community development is one way of supporting this process, by sharing the power, skills, knowledge and experience that give communities greater control over the conditions that affect their lives.

\section{THE CYCLING PROJECT}

We carried out this work with the aims of increasing action around cycling in low-income areas, and of investigating the links between cycling and social inclusion. In particular:

a) we wanted to find out whether, and how, it was possible to use cycling as an approach to increasing social inclusion:

- using its value for skill development, engaging young people, transport, and other locally relevant needs;

- targeting excluded groups, for example low-income communities; and

- involving local communities in action around cycling and in so doing helping build capacity and contribute to community development

b) we also wanted to investigate whether the social inclusion links had any relevance to helping engage a wider audience with cycling and increase action around cycling. For example, cycling as a tool to help deliver training for young people, or employment opportunities, is more widely relevant than cycling simply as a transport mode.

We were interested in local small-scale action around cycling as this is where the links with social inclusion issues have relevance. We were also interested in carrying out research to inform and learn from the action.

We began with a general investigation of existing action around cycling, and at the same time started work to develop new cycling-related action in low-income areas. Initially we took the approach of leading the development of new action ourselves, working to establish pilot cycling projects in deprived areas, with links to social inclusion. This initial work led us to develop and run a programme of support to help others take action and set up their own cycling projects. At all stages we recorded data and information for our research. 


\section{METHOD}

\section{Our approach to the work}

When we set out to do this work, our interest was in how we could promote cycling at a local community level and maximise the positive social inclusion outcomes associated with this activity. We were especially interested in the apparently wide range of issues that cycling projects seemed able to link for example health, training, job creation, service provision, transport, and the environment.

We carried out an initial scoping study which gave us a clear picture of the types of work that were being done in relation to cycling and cycle promotion in the UK There was little work, especially on a national scale, aimed at promoting and increasing small-scale community based cycling projects and making the links to social inclusion that we were interested in.

This lack of existing activity meant that in order to investigate these issues we needed to instigate the action ourselves and research the process and results as we progressed - to take an action research approach.

\section{Progress and organisation of work}

We started this work in June 1998. The first stage involved gathering information nationally, using a postal questionnaire about cycling initiatives that were already taking place and incorporating this information, along with details about the initiatives, into a database. At the same time we began to investigate the potential for setting up some live pilot cycling projects, with a housing estate focus, in London. This involved collecting information and ideas through telephone interviews with local authority cycling officers and local London Cycling Campaign representatives. The pilots were to help us investigate the outcomes and links that could result from cycling projects, and the way in which they could be encouraged and supported to develop.

At the end of this first stage we had established a database of national cycling initiatives, and had drawn up a shortlist of potential project ideas to take forward as pilots in London. We then chose 4 of these project ideas - a cycle taxi scheme, a cycle deliveries scheme, and two cycle recycling projects - and started work on developing them, with local partners, into 4 live pilots.

By the end of the second stage of work (December 1998) we had developed project plans and proposals and secured funding and local partners for all four of these pilots, although at this stage none of them were actually up and running. Two of the projects were handed to a local partner to manage their practical development and running. We continued to be involved in the other two until they were well established, and continue to have occasional involvement with them (as of August 2000).

By this point we had evidence that action around small-scale cycling projects could deliver positive outcomes relating to both cycling promotion and social inclusion, we had evidence of interest in this type of initiative, and we had experience of developing action. We were also starting to see how the links to social inclusion issues were an important part of the motivation for many groups and organisations in developing action around cycling in low-income areas. 
We decided that there was considerable scope and potential to promote and support more action on cycling projects by others. We thus developed a proposal for a third stage of work.

The result of this development was a nationally available programme of support to help community and youth groups set up small-scale cycling projects which we began work on at the beginning of 1999. The programme, called Bike up your life, had a core emphasis on the links between cycling projects and social inclusion - both to maximise positive outcomes and to engage as wide an audience as possible in low-income areas.

We have developed and run this programme for approximately a year. In this time we worked closely with eight youth groups in low income areas, helping to establish four new cycling projects and develop two existing cycle projects, including a community cycle pool, a mountain biking club, and a cycling proficiency training and cycling activities project. We are now in the process of working with another organisation that is taking over the running of the programme for the long term.

\section{Collecting information}

We have collected information and data all through this process in a variety of ways, as summarised in Appendix 3.

\section{The research questions}

Through doing this work we aimed to address the following general, and specific questions:

1) What benefits can small-scale cycling projects deliver?

More specifically under this question we wanted to look at:

- What relevance do they have to cycling promotion generally?

- What can they deliver in their own terms?

2) If small-scale cycling projects achieve certain desired goals, how can their adoption and establishment be supported? More specifically:

- What can we say about approaches to promoting this type of action by communities?

- How can we best support communities to set up cycling projects?

- What are the pros and cons of different approaches to achieving the development of small-scale cycling initiatives? 


\section{RESULTS}

We shall present the results as follows:

Stage 1 - Investigating existing action

- The cycling projects database - a national picture of existing action

- London wide picture of existing cycling activity by local authorities and non-local authority organisations

Stage 2 - Taking a lead in developing new action

- Potential pilot project ideas we identified in London

- $\quad$ The pilot projects - leading action to develop new cycling projects

Stage 3 - Supporting others to take action

- Introduction - the background to Bike up your life

- The response we received - who was interested in setting up projects, what action did they want to take and with what aims, what help did they say they needed to develop action

- Providing support - The approaches we took to providing support to help groups take action and the results seen. This section is split between the two approaches we took:

- The Basic support approach to supporting groups

- The intensive support approach - the Pedal Power programme

We have presented results covering evidence about existing action taking place around cycling, and three different approaches that we took to help develop new action. The results allow us to draw conclusions about the impacts that small scale cycling projects can have, what support they need to become established, and how different approaches fare in providing this support. We can also see the extent of interest in cycling projects and the range of different ideas and applications that exist.

\section{Stage 1: Existing action}

In this section we present the results from our national overview of existing cycling projects - the cycling projects database - and the results of our investigation of existing cycling action around cycling in London.

\section{The cycling projects database - a national picture of existing action}

\section{Summary}

We present the results from a national overview of 73 cycling projects, collected as a cycling projects database:

- A wide range of different projects were identified including, cycle recycling projects, a cycle circus, cycle pools and BMX and off road tracks

- The projects showed a reasonable geographical spread, with the public sector being the most often occurring type of organisation running projects. Projects led by community organisations were very poorly represented.

- Approximately half of the projects where the information was available had set up and annual running costs of under $£ 10,000$ 
- The projects reported a wide range of successful outcomes, including providing new services and facilities, promoting and increasing cycling, providing training and skills and successful financial outcomes.

- Non-cycling related aims such as crime diversion and building self-confidence were reported as aims behind setting up the projects by nearly twice as many groups as reported directly cycling related aims such as cycling promotion.

We used a written questionnaire to gather information about 73 cycling projects from around the UK (in 1998-9) and entered this onto a database. This database was designed to give us a general overview of the types of existing cycling projects. Updated information was collected from 26 of these that replied to a follow up questionnaire sent to all projects for which we had an address in 2000.

The full information contained in the database is available to anyone interested, electronically or in paper form (See Appendix 4 for details).

Table 3.1 gives a summary of the types of projects contained on the database (more details of the full range are given in Appendix 1). The three most common categories of project on the database are:

- Projects that provide activities or services, for example cycle recycling projects for young people, cycle taxi service

- Projects that promote and / or facilitate cycling, for example cycling to school or at work projects, work on integrating cycling with public transport modes

- Projects that provide facilities, for example cycle parking or hire, cycling centres offering a suite of facilities including changing, secure parking, retail.

There were a smaller number of examples of projects providing training or resources, and cycling-based business projects.

This summary represents a very wide variety of different projects including: a cycling circus; a specialist cycle manufacturer; cycle pools; BMX and off road tracks; a sponsored ride organiser; youth cycling projects including cycle recycling, cycle trips and cycle training.

The projects on the database show a reasonable geographical spread with concentrations in London, the South East and the North West (Table 3.2). As shown in Table 3.3 the type of organisation running projects most represented on the database is the public sector, both on its own and in partnership. This is followed by voluntary sector / charities and for profit businesses. Community organisations are very poorly represented.

Information on costs was only available for a relatively small number of the projects. Approximately half of the projects where the information is available cost under $£ 10,000$ to set up and over half have annual running costs of less than $£ 10,000$ (Table 3.4).

We have summarised the successful outcomes and outputs reported by projects on the database, by grouping them under broad categories (Table 3.5). The projects reported a wide range of successful outcomes with 'cycling promoted' being the most frequent category of outcome. Non-cycling specific outcomes such as delivering involvement and engagement with activities and action, or improved self-esteem, providing new services and facilities, and providing training are among the most often reported categories of outcome. These non-cycling specific outcomes can all have impacts on social inclusion, for 
example through improving peoples' skills, and ability to take action, and providing new facilities in areas where they are lacking. This is reflected in the basic aims involved in setting up projects that groups / organisations reported. Non-cycling related aims such as crime diversion, building self-confidence and gaining skills, were reported nearly twice as often as cycling related aims such as cycling promotion and promoting safer cycling.

Table 3.1

\begin{tabular}{|l|l|}
\hline Type of project & Number of this type \\
\hline Projects providing activities and services & 24 \\
Projects promoting / facilitating cycling & 20 \\
Projects providing facilities & 19 \\
Projects providing training & 4 \\
Cycling-based business projects & 4 \\
Projects providing resources & 2 \\
Total & 73 \\
\hline
\end{tabular}

Table 3.2 - Geographical spread (by Department of Environment, Transport and the Regions defined regions) of cycling projects on the Cycling projects database

\begin{tabular}{|l|l|}
\hline Region & Number of projects \\
\hline London & 11 \\
East & 5 \\
East Midlands & 6 \\
Yorkshire and the Humber & 2 \\
North East & 3 \\
Scotland & 1 \\
North West & 12 \\
West Midlands & 3 \\
Wales & 3 \\
South West & 6 \\
Total & 73 \\
\hline
\end{tabular}


Table 3.3 - Type of organisation running cycling projects from the Cycling projects database

\begin{tabular}{|l|l|}
\hline Type of organisation & Number of projects \\
\hline Public sector in partnership & 17 \\
Voluntary sector / charity & 16 \\
For profit business & 14 \\
Public sector & 13 \\
Community / Tenant Association project & 3 \\
Non-public sector partnership & 1 \\
Data missing & 9 \\
Total & 73 \\
\hline
\end{tabular}

Table 3.4 - Set up and annual running costs reported by cycling projects on the Cycling projects database

\begin{tabular}{|c|c|c|c|c|}
\hline Cost in $£$ & $\begin{array}{l}\text { Set up cost } \\
\text { (number of } \\
\text { projects) }\end{array}$ & $\begin{array}{l}\text { Cumulativ } \\
\text { e total (set } \\
\text { up costs) }\end{array}$ & $\begin{array}{l}\text { Annual } \\
\text { running } \\
\text { cost } \\
\text { (number of } \\
\text { projects) }\end{array}$ & $\begin{array}{l}\text { Cumulativ } \\
\text { e total } \\
\text { (annual } \\
\text { running } \\
\text { costs) }\end{array}$ \\
\hline Free & 1 & 1 & 3 & 3 \\
\hline Up to 500 & 2 & 3 & 2 & 5 \\
\hline $501-1,000$ & 2 & 5 & 1 & 6 \\
\hline $1,001-5,000$ & 6 & 11 & 4 & 10 \\
\hline $5,001-10,000$ & 4 & 15 & 1 & 11 \\
\hline $10,001-20,000$ & 4 & 19 & 1 & 12 \\
\hline $20,001-40,000$ & 5 & 24 & 2 & 14 \\
\hline $40,001-80,000$ & 3 & 27 & 2 & 16 \\
\hline $80,001-150,000$ & 2 & 29 & 0 & 16 \\
\hline Over 150,000 & 3 & 32 & 1 & 17 \\
\hline Data missing & 41 & & 56 & \\
\hline Total & 73 & & 73 & \\
\hline
\end{tabular}


Table 3.5 - Broad categories of successful outcomes reported by cycling projects from the Cycling projects database

\begin{tabular}{|l|l|l|l|}
\hline Successful outcome reported & $\begin{array}{l}\text { Number of } \\
\text { times it } \\
\text { was } \\
\text { reported }\end{array}$ & $\begin{array}{l}\text { Successful outcome } \\
\text { reported }\end{array}$ & $\begin{array}{l}\text { Number of } \\
\text { times it } \\
\text { was } \\
\text { reported }\end{array}$ \\
\hline $\begin{array}{l}\text { Cycling promoted } \\
\text { Project successful in itself (for } \\
\text { example met own targets, } \\
\text { project popular, success has led } \\
\text { to expansion, project } \\
\text { sustainable) }\end{array}$ & 36 & $\begin{array}{l}\text { Has provided training and } \\
\text { skills }\end{array}$ & 11 \\
$\begin{array}{l}\text { Has delivered involvement, } \\
\text { engagement and/or self- } \\
\text { improvement for users }\end{array}$ & 21 & $\begin{array}{l}\text { Positive environmental } \\
\text { impact } \\
\text { User satisfaction }\end{array}$ & 7 \\
$\begin{array}{l}\text { Provides new, and/or uses } \\
\text { existing, services and facilities }\end{array}$ & 20 & $\begin{array}{l}\text { Has achieved joining-up / } \\
\text { linking of issues } \\
\text { Has provided promotion for } \\
\text { the organisation(s) involved }\end{array}$ & 5 \\
\hline $\begin{array}{l}\text { Has increased cycling } \\
\text { outcomes }\end{array}$ & 18 & $\begin{array}{l}\text { Promoting or improving } \\
\text { health }\end{array}$ & $\begin{array}{l}\text { Total, reported by 54 } \\
\text { projects } \\
\text { Reduced cycle crime }\end{array}$ \\
\hline $\begin{array}{l}\text { Has had a positive impact } \\
\text { on transport in general }\end{array}$ & 2 \\
\hline
\end{tabular}




\section{London wide picture of existing cycling activity by local authorities and non-local authority organisations}

Summary

We present the results of an investigation into existing activity around cycling in the 32 London boroughs by local authorities and non-local authority groups:

- Work around cycling in the majority of London borough authorities was confined to infrastructure and facility provision, for example cycle lanes and cycle parking, training and promotion and planning work. Very few borough authorities were carrying out local project work involving local communities

- Non-local authority community or small-scale local cycling projects were reported in 8 boroughs

In order to get a picture of existing activity around cycling in London, with a view to identifying potential locations for setting up pilot projects:

- We carried out telephone interviews with cycling officers or sustainable transport officers in 31 of the 32 London boroughs. The remaining borough responded in writing. We asked what activity was going on in their borough around cycling, both in terms of local authority and non-local authority activity.

- We also carried out telephone interviews with 14 of the 33 borough branches of the London Cycling Campaign (LCC). In these cases we asked:

- what activity their Cycling Campaign group was involved in

- what their local authority was doing around cycling and how they rated them in this regard

- whether they knew of any other activity going on in their borough around cycling, for example community based projects

The results of this work are summarised below:

Table 3.6 shows that local London borough authority activities around cycling are confined principally to the 'conventional' activities of: infrastructure and facility provision, for example cycle lanes, sign posting and parking; training and promotion; policy / planning work. A small number of borough authorities were carrying out sport and leisure cycling activities. Very few reported any local project work involving local communities. Non-local authority groups were largely involved in physical / infrastructure provision, cycle promotion and training (Table 3.7). Non-local authority community or small-scale local cycling projects were reported in 8 boroughs (Table 3.7). 
Table 3.6 - Range of different activities around cycling carried out by the London boroughs (Total 32), as reported by local authority cycling officers and local London Cycling Campaign representatives

\begin{tabular}{|l|l|}
\hline Type of activity & $\begin{array}{l}\text { Number of } \\
\text { boroughs carrying } \\
\text { it out }\end{array}$ \\
\hline $\begin{array}{l}\text { Physical provision for cycling, for example signing, road markings. } \\
\text { Providing facilities, for example cycle parking }\end{array}$ & 17 \\
$\begin{array}{l}\text { Partnership work i.e. cycling work with non-local authority } \\
\text { partners }\end{array}$ & 15 \\
$\begin{array}{l}\text { Incorporating cycling into planning and / or policy } \\
\text { Training i.e. cycle training on and / or off road for adults and / or } \\
\text { children } \\
\begin{array}{l}\text { Development work, for example, developing ideas and plans for } \\
\text { new projects }\end{array}\end{array}$ & 14 \\
$\begin{array}{l}\text { Promotion / providing information, for example cycle maps and } \\
\text { leaflets } \\
\text { Sport and leisure }\end{array}$ & 13 \\
$\begin{array}{l}\text { Providing equipment, for example selling safety equipment at low } \\
\text { prices }\end{array}$ & 4 \\
\hline
\end{tabular}

Table 3.7 - Range of different activities around cycling carried out by non-local authority groups / organisations in all London boroughs (Total 32), as reported by local authority cycling officers and local London Cycling Campaign representatives

\begin{tabular}{|l|l|}
\hline Type of activity & $\begin{array}{l}\text { Number of boroughs } \\
\text { where is taking place }\end{array}$ \\
\hline Physical provision / infrastructure & 13 \\
Community or small-scale cycling project & 8 \\
Facilities & 4 \\
Training & 4 \\
Sport / leisure & 4 \\
Cycling survey & 1 \\
Policy or lobbying work around cycling & 1 \\
\hline
\end{tabular}




\section{Results - Stage 2: Taking a lead in developing new action}

Here we present the results of our involvement in establishing new pilot cycling projects in London, including our original shortlist of potential project ideas, and the actual four pilot projects we developed.

\section{Potential pilot project ideas identified in London}

Summary

We present a summary of 15 potential ideas for pilot projects from 11 London boroughs, including training projects, cycle parking provision, cycle centres and a promotional campaign.

In order to develop live pilot projects based in low-income areas in London we used the information gathered from cycling officers and local London Cycling Campaign representatives, in some cases backed up by further research, to draw up a shortlist of 26 possible projects for development, in 11 London boroughs. We based this short-listing process on the potential for action and chose areas where:

- the cycling officer expressed an interest in setting up a pilot project and/or

- the borough seemed active and offered the potential for setting up a cycle project

These possible projects for development were either ideas for a specific project or instances where there seemed to be good potential for setting up a project (for example good location, or active person) but no idea for a specific project.

15 of the 26 possible projects for development were ideas for specific projects. The ideas range from training projects and cycle deliveries, to cycle recycling projects, cycle parking facilities and cycle taxis. Three were ideas for quite large-scale cycle centres and one was for a promotional campaign. Four of the ideas were purely cycling related and two purely social inclusion related, while the remaining 5 were a mixture of the two.

The most common things needed to progress the projects further were partners and funding, followed by more development work. 


\section{The pilot projects - leading action to develop new cycling projects}

Summary

We present the results from our involvement in establishing four pilot projects in Hackney and Lewisham:

- We helped establish: a cycle taxi service for elderly people; a cycle grocery delivery service for sheltered housing residents; a cycle recycling project for young people; and a cycle mechanics and on-road riding training project for young people

- The projects achieved a wide range of positive outcomes, including 'at risk' young people being engaged in challenging activities, new services being provided in response to an established need, local people being employed and young people receiving training

- We had a wide ranging involvement and impact on the pilot projects, form helping bring the projects into existence, through involving partners and developing project plans, to raising funding. Two pilots were taken forward by another organisation once funding and project plans were in place. We remained involved in the other two, securing premises, recruiting people to run the projects and having an on-going steering group and troubleshooting role.

From the shortlist of ideas in 11 boroughs, we chose to concentrate on project ideas in two boroughs, Hackney and Lewisham. These were chosen because they seemed to offer the most interesting potential for establishing pilot projects in terms of a mix of factors, in particular: ideas for projects; potential project partners; potential housing estates on which to base them; and evidence of local need. Both of these boroughs are among the top 15 most deprived local authority districts according to the 1998 Index of Local Deprivation ${ }^{3}$.

Once we had chosen these areas, we started talks with project partners in each borough and developed practical pilot projects from that point.

The following projects were chosen:

- A cycle delivery project supplying housebound Housing Association tenants with groceries and other small items in Hackney (Pilot 1).

- A cycle maintenance and safe cycling training project for young people, involving a 10 week course of training and activities at three adventure playgrounds in Hackney (Pilot 2).

- A cycle taxi project providing a door-to-door flexible local transport service for elderly people on the Downham estate in Lewisham, in response to a need identified through local consultation (Pilot 3).

- A cycle recycling project on Downham Estate in Lewisham where young people receive cycle maintenance training and involvement in a stimulating activity through recycling old cycles. The finished cycles have been donated to low-income families and the young people who worked on them (Pilot 4).

The following section gives a brief overview of the results of the projects, the part we played in developing them and the impact our involvement had. Case studies giving more detail about the process involved in developing, setting up and running each pilot project, and the outcomes that were recorded from each can be found in Part II of this report.

\footnotetext{
${ }^{3}$ Bringing Britain Together, Social Exclusion Unit (1998)
} 


\section{Pilot projects - summary of outcomes and our involvement and impact}

The pilot projects again illustrated the wide range of impacts that cycling projects based in low-income areas can have, such as providing new services, increasing and promoting cycling, providing training, engaging young people in rewarding activities, and bringing in money. The outcomes they achieved confirmed many of those reported by the database projects, and provided more detailed information about these general outcomes. Table 4.1 presents the range of outcomes and outputs that the pilot projects reported. These were based on internal monitoring by the projects, formal and anecdotal feedback from users, and personal reports from the people running and working on the projects. The table shows how the outcomes reported illustrate in more detail the most often reported outcomes from the database projects (database outcomes taken from Table 3.5).

All four pilots received funding from the Ashden Trust, which was already involved in the work. Three of the pilots $(1,3$, and 4$)$ generated match funding from other organisations (between $£ 7,000-12,000$ each). In the two Lewisham pilots this came from a local Single Regeneration Budget, and in the case of the cycle taxis Lewisham borough council also contributed some funding. In the Hackney cycle deliveries pilot the match funding came from New Islington and Hackney Housing Association. The forth pilot had secured match funding from a Single Regeneration Budget for the area, but the project changed part way through development and moved location so this money was no longer accessible.

Table 4.2 summarises the range of ways in which we were involved in the development of the pilot projects and how this impacted on them. At the beginning, our involvement led to the inception of two of the project ideas and in the other two cases helped catalyse their development past the idea stage. The fact that we were able to commit time to developing the ideas into project proposals / plans and to raising money meant that action was developed much faster than it would otherwise have been and in two cases developed when it probably would not otherwise have been at all. This was because other organisations who were involved with the ideas were not able to commit development time, at least until funding had been secured.

In one case, the cycle taxi project, the fact that we were willing to take a lead in developing the project and that we had some funding available to put towards establishing it meant that the project could go ahead. The project has proved successful in terms of delivering a popular service to elderly people in a low-income area (based on data from informal and formal user feedback), and meeting an existing need that had been established through local consultation. It has allowed elderly people to make journeys that they simply could not before the service was set up, and to get help with shopping and home delivery that they previously had to rely on friends and family for. However because it was such an 'experimental' idea that had not been tried in this way before it was unlikely that it would ever have been established otherwise.

With the two Hackney projects a partner was available to take over the project development once we had secured the funding and developed a proposal / plan and so we just had to agree steering groups and management structures and hand over the projects. In Lewisham there was no such partner able to take on this role and so we remained involved in the practical setting up and running of the projects.

This involved sorting out practical details such as securing premises and recruiting staff, as well as organisational matters such as setting up and participating on steering groups, 
working with the project co-ordinators on practical running issues, and troubleshooting help with specific problems, for example securing on-going funding, monitoring, and involving new partners.

Table 4.1

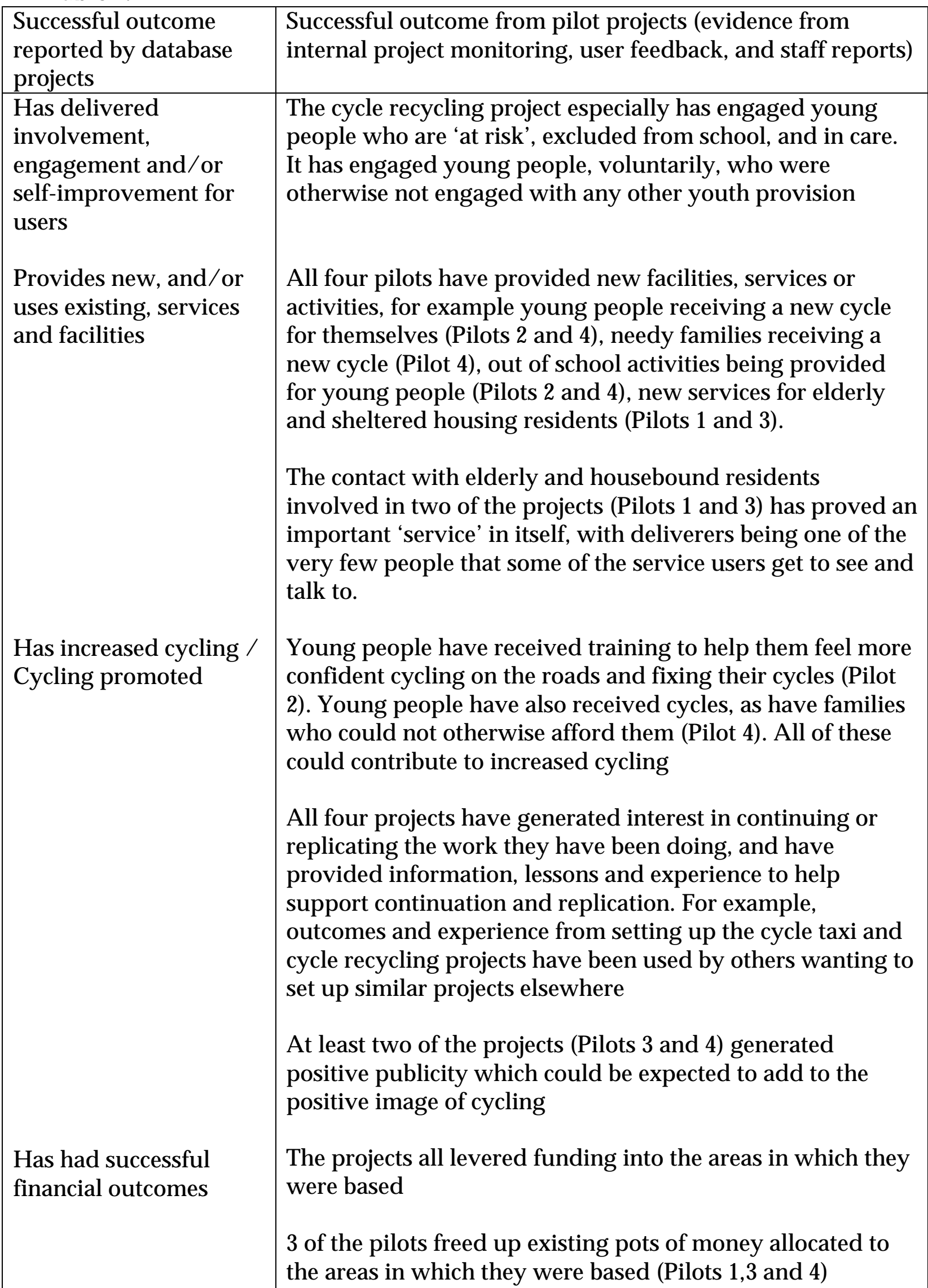




\begin{tabular}{|l|l|}
\hline & $\begin{array}{l}\text { The cycle taxi service has successfully started generating its } \\
\text { own income in a number of ways } \\
\text { All of the projects have employed people in their running - } \\
\text { in all but one case (Pilot 2) this included people from the } \\
\text { local area }\end{array}$ \\
$\begin{array}{l}\text { Has provided training } \\
\text { and skills }\end{array}$ & $\begin{array}{l}\text { Training in cycle maintenance and on-road safe cycling for } \\
\text { young people (Pilots 2 and 4) } \\
\text { Cycle taxi drivers have received training in operating the } \\
\text { vehicles and in working with elderly people }\end{array}$ \\
$\begin{array}{l}\text { The cycle taxi and delivery employees have learnt a lot } \\
\text { about working with elderly and housebound people }\end{array}$ \\
$\begin{array}{l}\text { The cycle mechanic and trainers involved in the cycle } \\
\text { recycling and maintenance training projects have learnt new } \\
\text { skills relating to working with and teaching young people }\end{array}$ \\
$\begin{array}{l}\text { Positive envective taxi and delivery service being provided } \\
\text { impact }\end{array}$
\end{tabular}


Table 4.2

Part I - from inception of idea to having project plan and funding in place

\begin{tabular}{|l|l|}
\hline $\begin{array}{l}\text { Involvement by LSE Housing cycling } \\
\text { project }\end{array}$ & Impact \\
\hline $\begin{array}{l}\text { Catalyst for the inception of the } \\
\text { projects }\end{array}$ & Project ideas brought into existence \\
$\begin{array}{l}\text { Identifying, involving and } \\
\text { negotiating with partners }\end{array}$ & $\begin{array}{l}\text { Partners involved in, and committed } \\
\text { to, helping develop the projects }\end{array}$ \\
$\begin{array}{l}\text { Taking a lead in researching } \\
\text { necessary information and } \\
\text { developing written project proposals }\end{array}$ & $\begin{array}{l}\text { Funding secured from partners } \\
\text { taking action }\end{array}$ \\
$\begin{array}{l}\text { Existence of a project plan allows } \\
\text { partner organisations to justify more } \\
\text { involvement and helps sell idea }\end{array}$ \\
\hline Raising funding for the projects & $\begin{array}{l}\text { Written proposal allows fundraising } \\
\text { to the project / take over project } \\
\text { development }\end{array}$ \\
\hline $\begin{array}{l}\text { Funding secured for projects } \\
\text { purtners to justify more commitment }\end{array}$ \\
\hline
\end{tabular}

At this point, once the project plan and funding were in place the two projects in Hackney developed in a different way than those in Lewisham. In the two Hackney pilots, a partner organisation took on the development of the project and we had very little involvement from then on. In the two Lewisham pilots there was no partner willing to take on this role and so we remained involved in the practical setting up and running of the projects. Once we had negotiated and completed the hand-over of the Hackney pilots our involvement in them ceased and so the following table applies only to the Lewisham pilots. 
Part II - from having project plan and funding in place onwards

\begin{tabular}{|l|l|}
\hline Involvement & \begin{tabular}{l} 
Impact \\
\hline Setting up steering groups \\
project to move forward \\
Allowed projects to run more \\
independently once they were set up
\end{tabular} \\
$\begin{array}{l}\text { Involvement with securing premises } \\
\text { and equipment } \\
\text { to run the projects }\end{array}$ & $\begin{array}{l}\text { Necessary components in place for } \\
\text { project to start running }\end{array}$ \\
Participating in steering groups & $\begin{array}{l}\text { Person to manage the practical day- } \\
\text { to-day running of the projects and } \\
\text { Workers to deliver the services }\end{array}$ \\
$\begin{array}{l}\text { Troubleshooting help with specific } \\
\text { problems }\end{array}$ & $\begin{array}{l}\text { Help with keeping the projects } \\
\text { running and keeping the partners } \\
\text { involved and active }\end{array}$ \\
\hline
\end{tabular}




\section{RESULTS - Stage 3: \\ Supporting others to take action through the Bike up your life programme}

In this section we give an introduction to the Bike up your life programme. We then present results covering the response we got to Bike up your life, and the support that we provided, including both the basic support programme we ran, and the intensive Pedal Power support programme we ran.

The work on developing the pilot projects, and setting up the cycling projects database produced enough evidence for the positive power of small-scale cycling projects, and enough evidence of widespread interest in such projects, to warrant further work in the area.

In late 1998 we proposed to the Ashden Trust the idea of setting up a programme to support community groups to develop their own cycling projects, rather than taking a lead on setting projects up ourselves, as we had with the pilots. In this way our resources could be used to affect more projects: we could promote the idea of cycling projects to others, and provide support, information and expertise to help them realise their own projects, and we could establish a replicable method of supporting cycling projects through community initiatives. Since groups would be setting up the projects themselves, this would lead to the additional benefit of their building their own capacity for further action - i.e. community development would be added to the other positive social inclusion outcome that we had seen in the pilot projects. We called the programme Bike up your life.

Bike up your life was designed as a national programme of support to help community groups set up small-scale cycling projects. It was designed to achieve the aim of:

'Promoting and increasing cycling at the community level by linking it to community and social inclusion issues, while at the same time carrying out research to support this effort and to produce results relevant to social exclusion and cycling promotion more generally.'

As indicated in the above aim, we saw communities and their interests as the starting point for our work. We were promoting cycling, but as a relevant tool to community needs and interests, not just as an end in itself.

We not only emphasised this in our advertising, but also adopted an approach in Bike up your life's main programme of support that was informed by community development as well as cycling.

The support we offered was split into two approaches:

- We offered an intensive programme of support, called Pedal Power, to groups wanting to set up cycling projects, incorporating training, access to a small grants fund provided by the Ashden Trust, and general ongoing advice and 'hand-holding'. This was offered to youth groups in low-income areas, and limited to 10 groups. 
- We also offered basic information and advice in writing and by telephone to any groups or individuals who wanted help.

This support was backed up by an information resource that we built up, including:

- Our cycling projects database

- Information and advice sheets

- Headed paper and logos, to help give groups more credibility when trying to elicit support from elsewhere, and a sense of belonging to a larger group / network

- General and specific knowledge and experience built up from our involvement in setting up pilot projects and researching cycling initiatives

\section{Response to Bike up your life}

Under this heading we present our findings related to the response we received to Bike up your life, covering:

- how we advertised the programme

- the initial response we got, in way of enquiries about the programme

the detailed applications for support

- an investigation of groups that showed an initial interest in the programme but did not apply for support

Summary

- We received 150 queries about the programme and 43 written requests for support

- We received 15 applications for the Pedal Power intensive support programme that was available only to youth groups. We received 28 applications for the Basic support programme from a mix of groups, including voluntary sector organisations / charities, and tenant and resident organisations

- Groups applying for support were proposing to do a range of different cycling related work. The most frequently proposed activities were cycle recycling or maintenance projects and cycle trips or cycle club activities

- These proposals were reflected in the aims and goals behind the proposals. The most common aims were related to involving and engaging young people in an activity and achieving selfimprovement for young people. Aims directly relating to cycling were less frequent

- The thing that most groups said they needed to help them set up projects was funding, followed by contact with others doing similar things and specific information and advice

\section{Promotion and advertising}

In the first half of 1999 we put out adverts about Bike up your life in 12 different youth, cycling and community development newsletters / publications, for example National Youth Agency magazine, Cyclists Touring Club magazine, and Tenant Participation Advisory Service newsletter (See Appendix 3 for a full list).

We also sent out direct publicity material through 5 networks, including Principal Youth Officers for each local authority in England, projects on our cycling projects database, and Crime Concern local projects (See Appendix 2 for a full list).

We did not undertake any active promotion or advertising after this original push. 


\section{Queries}

From April 1999 to the end of July 2000 we had received 150 queries about Bike up your life.

Table 5.1 shows the geographical spread in responses to our publicity, by Department of Environment Transport and the Regions defined regions. The highest responses were from the North West, London, Yorkshire \& the Humber, the East Midlands and the North East, in that order. We had much lower responses from the East, West Midlands, South West, Wales and Scotland. This spread is similar to that seen among the database projects, except for a marked increase in response from the East Midlands, Yorkshire and the Humber and the North East in the Bike up your life queries. We do not have the information to explain these differences.

\section{Table 5.1}

\begin{tabular}{|l|l|}
\hline Region & Number of projects \\
\hline London & 21 \\
East & 19 \\
East Midlands & 17 \\
Yorkshire and the Humber & 19 \\
North East & 15 \\
Scotland & 1 \\
North West & 25 \\
West Midlands & 8 \\
Wales & 4 \\
South West & $\mathbf{1 5 0}$ \\
National Organisations & 3 \\
\hline
\end{tabular}

\section{Written applications}

In response to each query we sent out an 'application pack'. This included a flyer about Bike up your life, Information about the support we could offer and an application or request form.

We received a total of 15 application forms for the Pedal Power programme and 28 request forms for Basic support. 
The following sections present information on the type of group asking for support, what they wanted to do and their underlying aims, and what help they said they needed to do it.

Type of groups applying for support

Table 5.2 shows the type of organisation applying for Bike up your life support. The Pedal Power programme was only open to groups working with young people. Once this is adjusted for there is a fairly even spread of types of groups applying, including voluntary sector organisations / charities, campaigning / lobbying organisations, community, tenant and resident associations, and in one case a local authority.

What the groups wanted to do

Table 5.3 categorises what the groups applying to Bike up your life were proposing to do. The two most frequently proposed activities were cycle recycling or maintenance and cycle trips or cycle club activities. These were followed in frequency by safe cycle training and providing cycling equipment (including cycles and safety equipment). Less frequent suggestions included campaigning / lobbying, establishing mountain bike / BMX tracks, and cycling promotion / education activities.

The most frequent suggestions probably reflect the emphasis on cycle projects for young people, and the goals that groups were trying to achieve in setting up projects (see Table 5.5 , and comments, below).

It may also reflect what activities most readily come to mind in connection with cycling, and the fact that cycle recycling projects generally captured people's imagination and elicited enthusiasm. The largest group of projects on the cycling database was also cycle recycling projects.

What help they said they needed

In the application / request for we asked groups what they felt they needed to help them develop cycling projects. This was the help they needed in general, not necessarily related to what we were offering. The support that the most groups said they needed was funding (See Table 5.4). This was followed by contact with others doing similar things, and specific information and advice. Requests for capacity building support, i.e. hand -holding, intensive help, information and advice on organisational matters, was asked for by the least number of groups.

This probably partly reflects the fact that approximately two thirds of the requests were for Basic support and not intensive Pedal Power support. However it may also reflect the fact that groups tended to be less aware of their needs in this area. This was illustrated by our work with the Pedal Power groups, a number of which needed capacity building support that they had not initially identified they needed. For example, two groups said that they could have done with getting access to the small grants fund sooner. However, in both cases they needed to carry out important project development before they could get funding, and in one case the group needed substantial support with preparing an acceptable grant application.

What they wanted to achieve by setting up a cycling project

Table 5.5 shows that the most commonly stated aim was to deliver involvement, engagement and self-improvement for young people and the third most stated aim was 
also explicitly youth related aim (providing youth activity). The youth involvement category was stated as an aim by 27 groups, meaning that even when the 15 groups applying for Pedal Power are accounted for youth was still an important concern among groups.

The most popular aims relate quite closely to the activities that the groups were proposing to do to realise them. For example, cycle recycling / maintenance projects, the most popular proposed type of project, could potentially deliver the two most stated aims, i.e. youth involvement, engagement and self-improvement through participation in a stimulating activity that young people tend to find interesting; training and skills through the teaching of cycle maintenance techniques.

Directly cycling related aims and environmental aims are quite low on the list.

Table 5.2

\begin{tabular}{|l|l|}
\hline Type of organisation & Number of projects \\
\hline $\begin{array}{l}\text { Interested individual or group of } \\
\text { individuals }\end{array}$ & 3 \\
Voluntary sector / charity & 5 \\
Tenants or Residents Association & 2 \\
$\begin{array}{l}\text { Established youth group, project or } \\
\text { centre }\end{array}$ & 19 \\
Local authority & 1 \\
Data missing & 2 \\
Total & 39 (Out of 43 applying - 4 were \\
\end{tabular}


Table 5.3

\begin{tabular}{|c|c|c|c|}
\hline Proposal & $\begin{array}{l}\text { Number } \\
\text { of } \\
\text { proposals } \\
\text { to do this }\end{array}$ & Proposal & $\begin{array}{l}\text { Number } \\
\text { of } \\
\text { proposals } \\
\text { to do this }\end{array}$ \\
\hline $\begin{array}{l}\text { Recycling project / } \\
\text { maintenance workshop / } \\
\text { repair \& maintenance } \\
\text { service } \\
\text { Cycle trips, club, } \\
\text { activities } \\
\text { Safe cycle training - } \\
\text { proficiency, skills, on } \\
\text { road cycling } \\
\text { Provide equipment - } \\
\text { cycles, safety equipment, } \\
\text { spares - for loan / hire or } \\
\text { purchase } \\
\text { Cycle promotion / } \\
\text { education } \\
\text { Cycle maintenance } \\
\text { training }\end{array}$ & $\begin{array}{l}22 \\
20\end{array}$ & $\begin{array}{l}\text { Nothing specific - } \\
\text { general development of } \\
\text { existing cycling activities } \\
\text { Establish mountain bike } \\
\text { / BMX track } \\
\text { Accreditation scheme } \\
\text { Cycle leader training } \\
\text { Establish cycle parking } \\
\text { facilities / pick up drop } \\
\text { off point } \\
\text { Cycle post coding (for } \\
\text { security) } \\
\text { Campaigning / lobbying } \\
\text { Business skills training } \\
\text { Data missing } \\
\text { Total (from } 39 \text { groups) }\end{array}$ & $\begin{array}{l}2 \\
1 \\
1 \\
1 \\
1 \\
92\end{array}$ \\
\hline
\end{tabular}


Table 5.4 - Type of help that groups applying to Bike up your life said they needed for setting up projects

\begin{tabular}{|c|c|}
\hline Help needed & $\begin{array}{l}\text { Number of projects saying they } \\
\text { needed it }\end{array}$ \\
\hline $\begin{array}{l}\text { Funding \&/or resources, for example } \\
\text { bikes, premises, equipment }\end{array}$ & 35 \\
\hline $\begin{array}{l}\text { Contact with others doing similar } \\
\text { things }\end{array}$ & 29 \\
\hline Specific information / advice & 24 \\
\hline General information / advice / ideas & 13 \\
\hline Training for skills & 11 \\
\hline $\begin{array}{l}\text { Involving partners / 'selling' their } \\
\text { idea }\end{array}$ & 11 \\
\hline $\begin{array}{l}\text { Information / advice on } \\
\text { organisational matters, for example } \\
\text { how do you set up and run a project? }\end{array}$ & 7 \\
\hline $\begin{array}{l}\text { Hand holding for a specific task / } \\
\text { specific outside help } \\
\text { Ongoing hand holding / intensive } \\
\text { help }\end{array}$ & $\begin{array}{l}6 \\
2 \\
138 \text { (from } 39 \text { projects) }\end{array}$ \\
\hline Total & \\
\hline
\end{tabular}


Table 5.5 - What the groups applying to Bike up your life said they wanted to achieve by setting up a cycling project - i.e. their stated aims

\begin{tabular}{|l|l|}
\hline Aim & $\begin{array}{l}\text { Number of } \\
\text { groups stating }\end{array}$ \\
\hline Training and skills & 19 \\
Providing youth activity & 18 \\
Facilities and services - providing new and using existing & 17 \\
Health - promoting and actually improving & 16 \\
Promote cycling & 14 \\
Cycling for transport & 12 \\
Crime diversion & 10 \\
To access locality and countryside & 8 \\
Economic issues & 7 \\
Improve the environment & 6 \\
LA21 / sustainable development & 39 projects) \\
\hline Reduce cycle crime & 3 \\
\hline
\end{tabular}

\section{Non-applicants}

We investigated the groups that had shown an initial interest in Bike up your life but had not gone on to request help from us. We wanted to know whether this had anything to do with our approach, and whether there was anything we could change to increase the response rate.

We contacted a small sample of the projects who had enquired about Bike up your life and been sent an application / request pack but who had not applied to us for anything. We carried out a telephone questionnaire interview with 13 groups chosen at random, out of the 108 'non-applicants'.

We found that in the majority of cases there was little that we could have done to influence the groups who had not applied for support, and certainly the reasons they did not apply were unrelated to the support we were offering or the way in which we provided it. For half the groups the idea of setting up a project had turned out not to be relevant for them, fizzled out, or had come at the wrong time for their organisation. One group had never received our application pack. Two had missed the deadline for applying to the Pedal 
Power programme and so had not applied at all (Table 5.6). In these latter cases it is possible that we could have helped them under the Basic support programme and perhaps a follow up telephone call and a talk through what they needed might have resulted in our providing support.

\section{Continued relevance of "Bike up your life"}

We found that the idea of doing a cycling project was still alive - they had our information on file and the idea in the back of their minds - for 9 of the 13 groups.

Interest in Bike up your life was still there -7 of the groups requested that I send them our information again and / or keep them on our mailing list. In a number of cases our contacting them seemed to have re-sparked interest in the idea of a cycling project, for example one group was going to bring it up at an upcoming meeting.

Table 5.6 - Reasons given by groups for their initial enquiry about Bike up your life, and for not subsequently applying for support

\begin{tabular}{|c|c|c|c|}
\hline $\begin{array}{l}\text { Reason given for initial } \\
\text { enquiry }\end{array}$ & $\begin{array}{l}\text { Numbe } \\
\text { r of } \\
\text { groups }\end{array}$ & $\begin{array}{l}\text { Reason given for not } \\
\text { applying for support }\end{array}$ & $\begin{array}{l}\text { Number } \\
\text { of } \\
\text { groups }\end{array}$ \\
\hline $\begin{array}{l}\text { They were specifically } \\
\text { interested in the idea of } \\
\text { setting up a cycling project } \\
\text { They were exploring } \\
\text { general ideas for activities } \\
\text { and were interested in } \\
\text { cycling projects as one } \\
\text { possibility } \\
\text { They were working on } \\
\text { setting up a cycling project } \\
\text { (had started taking steps in } \\
\text { that direction) } \\
\text { Data missing } \\
\text { Total }\end{array}$ & $\begin{array}{l}2 \\
3\end{array}$ & $\begin{array}{l}\text { The idea of setting up a } \\
\text { cycling project turned out } \\
\text { to not be relevant to them } \\
\text { / fizzled out } \\
\text { It was the wrong time for } \\
\text { them as an organisation } \\
\text { They had missed the } \\
\text { deadline for Pedal Power } \\
\text { and specifically wanted to } \\
\text { apply for that part of it } \\
\text { They never received our } \\
\text { pack } \\
\text { They had passed our pack } \\
\text { on to another organisation } \\
\text { and so don't know } \\
\text { Data missing } \\
\text { Total }\end{array}$ & $\begin{array}{l}1 \\
3 \\
13\end{array}$ \\
\hline
\end{tabular}




\section{Providing support}

In this section we present our findings relating to the support we gave to other groups to set up cycling projects, through Basic support and through our intensive Pedal Power programme of support.

The 43 applications / requests for support we have had (as analysed above and presented in Tables $5.2-5)$, resulted in the following:

- 8 of were given a place on our Pedal Power programme of intensive support

- 3 were offered places on Pedal Power but dropped out of the programme for various reason

- 26 were provided with written Basic support

- We have failed to provide support for 3 (all of whom had requested Basic support)

- 3 were received too late to be included here (all three were requests for Basic support )

\section{Basic support}

\section{Summary}

- We provided Basic support to 26 groups, including general and specific information, contacts and specific advice.

- Our support had an impact on over half of the 14 groups who provided follow up information, in ways such as, directing thinking, giving ideas and contacts, giving confidence and legitimacy, and helping them secure funding

\section{What support we provided}

We have provided Basic support to 26 groups through a written response to their request. Table 5.4 showed the range of support requested by these groups (along with the groups given a place on Pedal Power, and those that dropped out). Table 5.7 summarises the support we have provided for 25 of these (the last one was provided too late to be included here). A detailed example of the Basic support we provided to one group is presented in Appendix 2.

Pre-prepared written information, and contacts for other groups, were the principal types of support provided. We delivered these through our own pre-written information sheets, a 'how to' manual provided by another project, our cycling project database, and some specifically researched contacts information. We also provided individually tailored responsive advice, suggestions or specifically researched information to approximately half of the groups. For example, ideas for raising funding and engaging interest, examples of project proposal documents, ideas on where to get support and equipment.

We helped two groups with publicising their work, and provided one with some reflective ribbon that had been donated to us.

As well as this 'formal' support we have provided small bits of advice, information and contacts over the telephone in a number of cases, for example putting people / organisations in touch with others, letting them know about other things going on. 
Table 5.7

\begin{tabular}{|l|l|}
\hline Support provided & $\begin{array}{l}\text { Number of groups } \\
\text { provided to }\end{array}$ \\
\hline $\begin{array}{l}\text { Information sheets and other pre-prepared } \\
\text { information, for example 'how-to' manual }\end{array}$ & 24 \\
$\begin{array}{l}\text { Contacts for other cycling groups / projects- } \\
\text { both from our database and specifically } \\
\text { researched }\end{array}$ & 24 \\
$\begin{array}{l}\text { Responsive advice / suggestions / or specifically } \\
\text { researched information on a range of topics }\end{array}$ & 12 \\
$\begin{array}{l}\text { Offered follow up help, for example suggested } \\
\text { they give us a ring to discuss their plans further }\end{array}$ & 4 \\
$\begin{array}{l}\text { Helped publicise what they were doing-i.e. } \\
\text { added them to our cycling projects database }\end{array}$ & 2 \\
$\begin{array}{l}\text { Provided them with reflective ribbon that we had } \\
\text { received as a donation, for use in cycle safety } \\
\text { work with young people }\end{array}$ & 1 \\
Total & $\begin{array}{l}\mathbf{6 7} \text { 'pieces' of support, } \\
\text { given to 25 groups }\end{array}$ \\
\hline
\end{tabular}

\section{What effect our support had and what the groups thought about it}

We managed to re-contact and interview 14 of the groups that had received Basic support to gather follow up information. We used carefully worded questions to avoid positive bias.

Did the support we gave have any impact on their work / projects?

Result 5.1 suggests that our support had an impact on over half of the groups that we got feedback from.

Table 5.8 presents the way in which the groups reported that our Basic support contributed to and/or impacted on their cycling work. This impact ranged from helping direct or focus thinking and giving ideas, to providing contacts and giving confidence / legitimacy to groups. In one case our support helped a group get funding for their work.

Result 5.1 - Shows the reported impact of the Basic support provided to groups

- 8 of the 14 groups questioned disagreed with the statement that

"The information sent to us by Bike up your life did not have any impact on our project"

1 group said that it had had a limited impact

5 agreed with the statement

- 8 of the 14 groups questioned agreed with the statement that:

"The information sent to us did help with a specific part of our project" 
1 said that it had had a limited specific impact

\section{5 disagreed}

Table 5.8

\begin{tabular}{|l|l|}
\hline Reported contribution & $\begin{array}{l}\text { Number of projects } \\
\text { reporting it }\end{array}$ \\
\hline $\begin{array}{l}\text { Helped direct or focus thinking / Gave ideas / } \\
\text { helped them decide what to do }\end{array}$ & 5 \\
$\begin{array}{l}\text { Gave them contacts (In one case this resulted in } \\
\text { partnership working) }\end{array}$ & 4 \\
$\begin{array}{l}\text { They have only used the information for reference } \\
\text {-it has had no specific impact }\end{array}$ & 3 \\
$\begin{array}{l}\text { Gave them confidence / legitimacy i.e. helped } \\
\text { them see that others were doing similar things } \\
\text { and they were not alone / what they were doing } \\
\text { made sense }\end{array}$ & 2 \\
$\begin{array}{l}\text { Helped them argue their case with the local } \\
\text { authority }\end{array}$ & 1 \\
$\begin{array}{l}\text { Helped them get funding - they used bits of our } \\
\text { written information for a successful funding } \\
\text { application }\end{array}$ & 1 \\
$\begin{array}{l}\text { Gave them specific information that they needed } \\
\text { Total }\end{array}$ & 1 \\
\hline
\end{tabular}

Continued relevance of "Bike up your life"

Following the follow up telephone interviews, which came between 6 to 12 months after the groups' initial requests for support, we were able to respond to 6 new requests for help that had come up during the interviews. This indicates that groups continue to need support on an ongoing basis.

What these groups had achieved

In the time between initial requests for support and our follow up interviews, three of the four groups that had been running no cycling activities when they first contacted us had developed totally new cycling activities. Of the 10 groups that had already been running cycling activities, nine had continued to run existing cycling activities and four had developed new cycling activities on top of their existing ones. This is shown in Table 5.9. 
Table 5.9 - Existing, ongoing and new cycling activity in 14 groups after having received Basic support

\begin{tabular}{|c|c|c|c|}
\hline & $\begin{array}{l}\text { Continued to run } \\
\text { some form of cycling } \\
\text { activity }\end{array}$ & $\begin{array}{l}\text { Developed some new } \\
\text { cycling activity since first } \\
\text { applying to us }\end{array}$ \\
\hline $\begin{array}{l}\text { Already } \\
\text { running some } \\
\text { cycling activity } \\
\text { when they } \\
\text { applied to us }\end{array}$ & 10 & 9 (1 missing value) & 4 \\
\hline $\begin{array}{l}\text { Not running } \\
\text { any cycling } \\
\text { activity when } \\
\text { first applied to } \\
\text { us }\end{array}$ & 4 & & 3 \\
\hline Totals & 14 & & $\begin{array}{l}7 \text { developed new cycling } \\
\text { activity } \\
12 \text { showed positive } \\
\text { outcomes (i.e. either } \\
\text { continued to run, or } \\
\text { developed new, cycling } \\
\text { activities) }\end{array}$ \\
\hline
\end{tabular}




\section{Intensive support - the Pedal Power programme}

In this section we give:

- an introduction to the Pedal Power programme

- a brief overview of the range of support we provided

- an overview of the groups participating

- a summary of the outcomes and outputs achieved by the groups and the impact that our support had on them

- a more detailed consideration of the support provided by, and impact of, the residential training courses

Summary

- We provided intensive support to eight youth groups in low-income areas, including, information and advice, training, small grants, and ongoing 'hand-holding' support.

- Four of the groups developed new cycling projects and two developed their existing cycling work further.

- All of the groups achieved positive outcomes, such as personal and group development, learning new skills, funding and resources secured, and new services and facilities. These resulted from the process of working on developing the projects, as well as from the finished projects themselves

- Our support impacted on the groups and their projects in many ways, including, helping gel groups into action, helping them gain practical and organisational skills, help with specific tasks.

In Part II of this report we present case studies giving more detail about the process each group went through, the outcomes that they achieved, and the way in which our support impacted on. Here we give a summary of this experience.

\section{Introduction}

From the 15 applications we had for the Pedal Power programme we offered a place to 10 groups. 2 of these dropped out, and a place was offered to another group that also dropped out. All three groups dropped out because of staffing problems that meant they could not commit to the programme. The groups were selected using the following guidelines with input from experienced grant givers from the Ashden Trust, LSE Housing, and Trafford Hall (the National Tenants Resource Centre):

- The groups had to meet the following criteria:

- the group should have links to the wider community

- they should be enthusiastic and committed

- they should have clear aims

- they should have an idea about how to achieve their aims, and this should be small scale and do-able

- Further to this we selected groups for whom we felt that the support we were offering was relevant, and needed

- We picked groups that we felt could, with the type of support we were offering, set up a project

- Where there was still a choice, we picked the group that needed our support the most i.e. seemed able to set up a project, but the was the most unlikely to do so without support

All the projects chosen involved young people and were based in low-income areas. 


\section{Support provided by the programme}

In the end 8 groups took part in our Pedal Power programme of intensive support. The groups received support from the following list:

- Two residential training courses covering capacity building and specific cycle related skills training

- Access to a small grants fund

- Written information and advice

- Telephone information and advice

- Ongoing contact, support and 'work chasing'

- 'Consultancy' support with specific tasks

- Group visits where advice and planning help was given (on top of the main aim which was to collect information for our research)

\section{Overview of groups participating in the Pedal Power programme}

Table 5.10 - Background information for the Pedal Power groups

\begin{tabular}{|l|l|l|l|l|}
\hline Group & Context & Where based & $\begin{array}{l}\text { Background, in } \\
\text { relation to } \\
\text { cycling }\end{array}$ & $\begin{array}{l}\text { Their aims when they } \\
\text { applied to Pedal } \\
\text { Power }\end{array}$ \\
\hline $\begin{array}{l}\text { Benwell } \\
\text { Bikers }\end{array}$ & $\begin{array}{l}\text { A cycle club } \\
\text { operating } \\
\text { within a } \\
\text { larger } \\
\text { regeneration } \\
\text { project }\end{array}$ & $\begin{array}{l}\text { The Benwell } \\
\text { area in } \\
\text { Newcastle's } \\
\text { West End }\end{array}$ & $\begin{array}{l}\text { They already ran } \\
\text { a regular after } \\
\text { school cycling } \\
\text { club for young } \\
\text { people in the } \\
\text { area, with skills } \\
\text { and planning } \\
\text { sessions, and } \\
\text { group cycle rides }\end{array}$ & $\begin{array}{l}\text { They were having } \\
\text { difficulties with } \\
\text { attendance, and } \\
\text { wanting to develop } \\
\text { their club and } \\
\text { membership }\end{array}$ \\
\hline Brook Club & $\begin{array}{l}\text { A dedicated } \\
\text { local } \\
\text { authority } \\
\text { funded } \\
\text { youth centre }\end{array}$ & $\begin{array}{l}\text { Sommerstown } \\
\text { area of } \\
\text { Portsmouth }\end{array}$ & $\begin{array}{l}\text { Their cycle } \\
\text { project was only } \\
\text { an idea when } \\
\text { they applied to } \\
\text { Pedal Power }\end{array}$ & $\begin{array}{l}\text { They wanted to set } \\
\text { up and run a cycle } \\
\text { recycling workshop } \\
\text { with business skills } \\
\text { training for young } \\
\text { people }\end{array}$ \\
\hline $\begin{array}{l}\text { Community } \\
\text { Links }\end{array}$ & $\begin{array}{l}\text { A large, well } \\
\text { established, } \\
\text { voluntary } \\
\text { charity that } \\
\text { runs a range } \\
\text { of } \\
\text { community } \\
\text { and youth } \\
\text { projects and } \\
\text { activities }\end{array}$ & $\begin{array}{l}\text { Borough of } \\
\text { Eewham in }\end{array}$ & $\begin{array}{l}\text { They had carried } \\
\text { out some one-off } \\
\text { cycling activities } \\
\text { before }\end{array}$ & $\begin{array}{l}\text { They wanted to set } \\
\text { up an ambitious suite } \\
\text { of cycling projects, } \\
\text { including a weekly } \\
\text { club, cycle recycling, } \\
\text { and fitness activities }\end{array}$ \\
\hline
\end{tabular}




\begin{tabular}{|c|c|c|c|c|}
\hline $\begin{array}{l}\text { Focus } \\
\text { Senior Club }\end{array}$ & $\begin{array}{l}\text { A youth club } \\
\text { for teenagers } \\
\text { based in a } \\
\text { youth centre }\end{array}$ & $\begin{array}{l}\text { Beavers estate } \\
\text { in Hounslow } \\
\text { West, West } \\
\text { London }\end{array}$ & $\begin{array}{l}\text { They had not run } \\
\text { any cycling } \\
\text { activities before, } \\
\text { but a volunteer } \\
\text { worker (who led } \\
\text { the project) had a } \\
\text { personal interest } \\
\text { in mountain } \\
\text { biking }\end{array}$ & $\begin{array}{l}\text { They wanted to run } \\
\text { regular mountain } \\
\text { biking activities for } \\
\text { young people }\end{array}$ \\
\hline $\begin{array}{l}\text { Landport } \\
\text { community } \\
\text { centre }\end{array}$ & $\begin{array}{l}\text { An } \\
\text { independent } \\
\text { community } \\
\text { centre }\end{array}$ & $\begin{array}{l}\text { Landport area } \\
\text { of Portsmouth }\end{array}$ & $\begin{array}{l}\text { They had only } \\
\text { been thinking } \\
\text { informally about } \\
\text { the idea of } \\
\text { setting up a } \\
\text { cycling project }\end{array}$ & $\begin{array}{l}\text { To set up a cycle pool } \\
\text { for users of the centre } \\
\text { and local residents, } \\
\text { maintained by young } \\
\text { people from the } \\
\text { centre. }\end{array}$ \\
\hline $\begin{array}{l}\text { Hackney } \\
\text { Quest }\end{array}$ & $\begin{array}{l}\text { A charity } \\
\text { providing } \\
\text { out of school } \\
\text { activities for } \\
\text { young } \\
\text { people }\end{array}$ & $\begin{array}{l}\text { Borough of } \\
\text { Hackney in } \\
\text { East London }\end{array}$ & $\begin{array}{l}\text { Had run some } \\
\text { one-off cycling } \\
\text { trips which } \\
\text { young people } \\
\text { had responded } \\
\text { positively to }\end{array}$ & $\begin{array}{l}\text { Did not have a } \\
\text { specific idea - they } \\
\text { just wanted to set up } \\
\text { a cycling project in } \\
\text { response to the } \\
\text { positive response this } \\
\text { activity got from the } \\
\text { young people } \\
\text { involved }\end{array}$ \\
\hline $\begin{array}{l}\text { Highfields } \\
\text { compact }\end{array}$ & $\begin{array}{l}\text { Single } \\
\text { Regeneration } \\
\text { Budget } \\
\text { youth project } \\
\text { based within } \\
\text { a youth and } \\
\text { community } \\
\text { centre }\end{array}$ & $\begin{array}{l}\text { Highfields } \\
\text { area of } \\
\text { Leicester }\end{array}$ & $\begin{array}{l}\text { Detached youth } \\
\text { work had } \\
\text { revealed an } \\
\text { interest in } \\
\text { cycling activities } \\
\text { among young } \\
\text { people. hey had } \\
\text { not run any } \\
\text { before applying } \\
\text { to Pedal Power }\end{array}$ & $\begin{array}{l}\text { They wanted to } \\
\text { establish a cycle } \\
\text { repair workshop and } \\
\text { cycle club, running } \\
\text { sessions on cycle } \\
\text { maintenance and } \\
\text { safety and offering } \\
\text { information and cycle } \\
\text { trips. They also } \\
\text { wanted to encourage } \\
\text { cycling proficiency } \\
\text { courses in the local } \\
\text { schools }\end{array}$ \\
\hline $\begin{array}{l}\text { Recycle-a- } \\
\text { cycle }\end{array}$ & $\begin{array}{l}\text { An } \\
\text { independent } \\
\text { youth project } \\
\text { with } \\
\text { charitable } \\
\text { status }\end{array}$ & $\begin{array}{l}\text { Based on a } \\
\text { housing estate } \\
\text { in East Cowes, } \\
\text { on the Isle of } \\
\text { Wight }\end{array}$ & $\begin{array}{l}\text { They were set up } \\
\text { originally as a } \\
\text { cycle recycling } \\
\text { project }\end{array}$ & $\begin{array}{l}\text { They wanted to } \\
\text { develop their existing } \\
\text { cycling project, } \\
\text { especially with } \\
\text { regards to links for } \\
\text { the young people to } \\
\text { higher education }\end{array}$ \\
\hline
\end{tabular}




\section{Summary of outcomes and our impact on the groups}

From the 8 groups participating in the Pedal Power programme of support, 4 groups developed totally new cycling projects, 2 of the groups developed their existing cycling projects, and 2 groups failed to set up cycling projects.

A wide range of positive outcomes was seen from all 8 groups (summarised in Table 5.11). These were reported by the groups formally and informally, and observed by the LSE Housing cycling project worker. These resulted both from the new and developed projects and, as importantly, from the process of working on developing the projects. The process of working on the projects, through the Pedal Power programme resulted in reported and observed outcomes such as: personal and group development, the learning of new skills by workers and young people, funding and resources being secured, positive publicity, networking with other groups, and in one case helped contribute to a volunteer gaining employment. The projects themselves resulted in reported and observed outcomes such as: new services, activities and facilities, young people taking exercise, cycles made safer, new skills for young people, personal development, and positive publicity.

These results indicate how the process of setting up projects is an important thing in itself, even before the results of the actual projects are considered. Many outcomes seen from the development process are capacity building related and show how an explicit inclusion of community development and capacity building in work with community groups can add its own important outcomes to those seen from the finished work.

Table 5.12 summarises the range of ways in which our support impacted on the groups and contributed to the positive outcomes seen (as reported by the groups and observed by our project worker). At the most fundamental level, our support helped bring about the action seen and make ideas into reality. This was achieved in a number of ways. The offer of support gelled groups into action, ongoing encouragement and contact kept them going, and the existence of an official programme that was working with them helped give their projects credence to win support from others.

We provided information and practical skills, and help with specific tasks. We also provided support with the organisational aspects of setting up projects, for example training in action planning and project management, help with writing proposals. We helped provide time for groups to work on their projects, for example at the training courses, and helped individuals and groups build capacity through training and personal development. 
Table 5.11 - Reported and observed positive outcomes from the Pedal Power projects Outcome
Young people and / or workers trained in new skills (both practical and
organisational)
New activities / services / facilities
Cycles made safer
New resources
Funding / 'in kind' support brought in
Positive publicity
Project development, for example new plans, plans developed
Links made with other groups
Young people taking exercise
Project perseverance / continuation / growth
Project involvement contributing to volunteer gaining employment

Table 5.12

\begin{tabular}{|l|}
\hline Impact \\
\hline Helped with organisational problems / needs \\
General information and advice \\
Specific information and advice \\
'Consultancy' help with a specific task / problem \\
Help with funding - either directly or help accessing other funding \\
Practical skills \\
Organisational skills \\
Time to focus on working on the project \\
Networking / contact with others \\
Personal development for young people and workers involved \\
\hline
\end{tabular}




\section{Project failures}

The two groups that failed to set up or develop projects add to the evidence about blocks to setting up projects. In both cases the single biggest factor stopping the groups developing cycling projects was the fact that they could not commit enough development time to doing so. Based on the groups' reports and our assessment, it seemed likely in both cases that had they been able to dedicate more development time they would have been able to overcome other barriers and establish projects.

\section{Residential training courses}

The residential training courses played an important part in providing support to the groups and helping them set up projects. We ran two courses, one at the beginning of the programme of support and the second 6 months later. The aim, and way this was achieved for each course is outlined in Table 5.13 below, followed by results relating to the outcomes and impacts the courses had.

Table 5.13 - Aim and content of the Pedal Power residential training courses

\begin{tabular}{|c|c|}
\hline Aim & Course content \\
\hline $\begin{array}{l}\text { Course } 1 \\
\text { - } \quad \text { To help build the groups' } \\
\text { identities } \\
\text { - } \text { To help them develop skills in } \\
\text { goal setting, action planning, } \\
\text { project development and project } \\
\text { management i.e. a basic backbone } \\
\text { of skills needed when setting up } \\
\text { any practical project } \\
\text { To work with the groups to help } \\
\text { them get a clearer idea of what } \\
\text { they were working towards, how } \\
\text { to plan getting there, and to } \\
\text { realise the beginnings of those } \\
\text { plans } \\
\text { Gain support and motivation from } \\
\text { meeting other like minded people } \\
\text { and groups working on similar } \\
\text { projects and meeting similar } \\
\text { challenges }\end{array}$ & 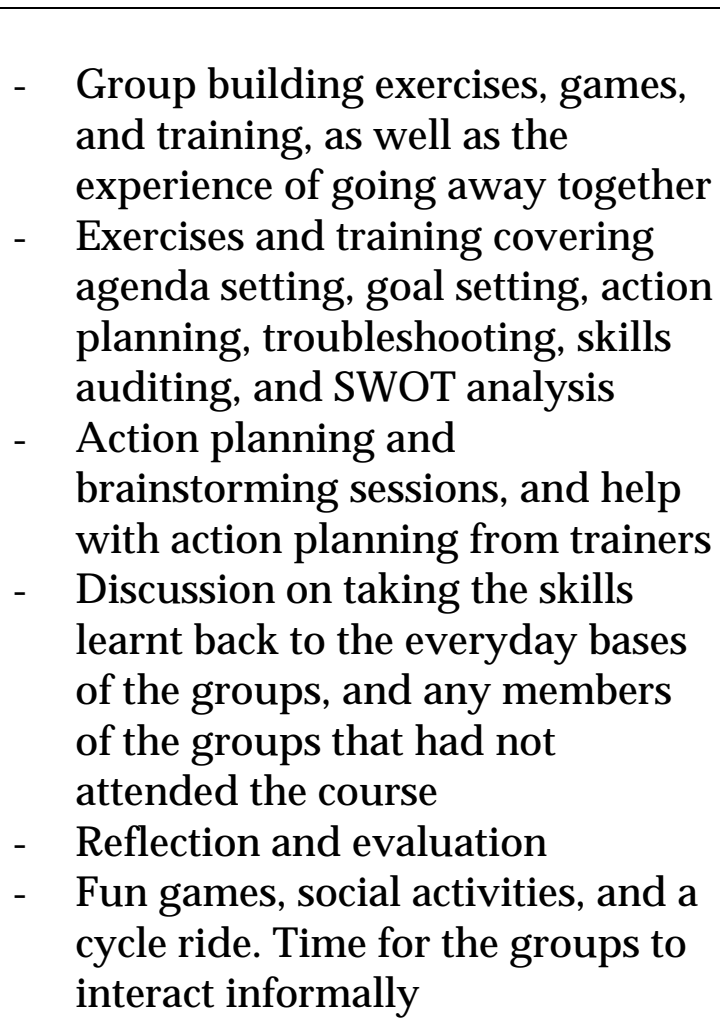 \\
\hline 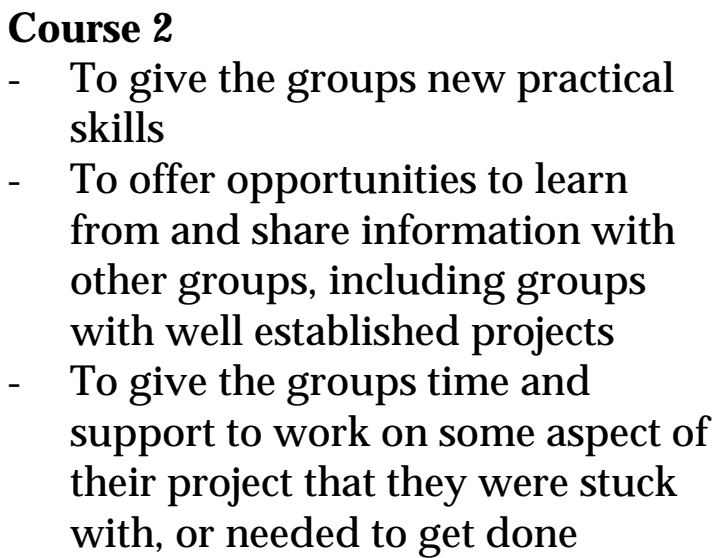 & $\begin{array}{l}\text { - Cycle maintenance training and } \\
\text { advice with an experienced cycle } \\
\text { mechanic } \\
\text { - On-road safe cycle training, } \\
\text { including training on how to teach } \\
\text { others safe on-road techniques } \\
\text { - Guest up and running cycle } \\
\text { projects attended and gave talks } \\
\text { about their work, followed by } \\
\text { discussion and question - answer } \\
\text { time }\end{array}$ \\
\hline
\end{tabular}




\begin{tabular}{|c|c|}
\hline $\begin{array}{l}\text { - To generally re-invigorate the } \\
\text { groups' momentum and } \\
\text { enthusiasm }\end{array}$ & $\begin{array}{l}\text { An open task session where } \\
\text { trainers and resources (for } \\
\text { example computers, resource } \\
\text { room) were available to help the } \\
\text { groups work on some important } \\
\text { task for their project, or get help } \\
\text { with something they were stuck } \\
\text { on } \\
\text { - Reflection and evaluation } \\
\text { - Fun games, social activities, and } \\
\text { time for the groups to interact } \\
\text { informally }\end{array}$ \\
\hline
\end{tabular}

\section{Support provided by the courses}

The participants who attended the courses reported a range of different types of support that they had received from the courses, as summarised in Table 5.14. The support can be categorised in the following groups:

- The participants received new skills, both organisational and 'practical'

- The courses helped build confidence in the participants and groups, gave opportunities for personal development, and helped give a sense of comradeship and belonging to a larger group of people working on similar things

- They provided opportunities for the groups to receive help and advice with specific aspects of their individual projects

- The courses provided opportunities for networking and learning from others working on similar ventures

Table 5.14 - Range of support provided by the Pedal Power training courses, as reported by participants

Cycle maintenance skills

Organisational skills including, action planning and team building

Networking / meeting other groups

Safe cycling skills and safe cycling teaching skills

Personal development and confidence building

Specific help and advice

Sense of comradeship and being part of a bigger group / organisation

Impact on cycle projects

- After the first course 16 of the participants reported that participating on the course, and what they had learned, would be 'helpful' or 'very helpful' in setting up their cycling projects.

The $17^{\text {th }}$ participant thought the course would be 'quite' helpful. 
After the second course all 10 participants who completed an assessment form reported that the course would be 'helpful' or 'very helpful' for their projects.

- After the first project 11 participants said they would do something differently as a result of having attended the course, while four said they would not.

After the second course 7 said they would do something differently, and 2 said they would not.

The range of things that participants said they would do differently as a result of the courses is presented in Table 5.15, indicating the ways in which the training courses impacted on the participants and groups.

The courses had an impact on the groups in terms of their work on their cycling projects, for example in the way that groups went about planning and setting up the projects, and what they would include. They also had a wider impact on the groups in terms of their organisational skills that they would use for the cycling projects but also any other work they do, for example by imparting planning and management skills. Finally, they impacted on the cycle safety and practical cycling knowledge of the participants, and in one case the amount of cycling one participant planned to do. Many of these impacts were things that would be taken back by the groups and passed on to others, for example safer on-road riding techniques, technical knowledge, organisational skills.

Table 5.15

\begin{tabular}{|c|c|}
\hline Area of impact & $\begin{array}{l}\text { Example of what the participant said they would do as a } \\
\text { result of the course }\end{array}$ \\
\hline $\begin{array}{l}\text { Better cycle } \\
\text { safety }\end{array}$ & $\begin{array}{l}\text { - } \\
\text { - }\end{array}$ \\
\hline Practical tasks & $\begin{array}{ll}\text { - } & \text { set up cycle in correct riding position } \\
\text { - } & \text { know what tools to take out on a cycle ride } \\
\text { - } & \text { know how to check a frame for crash damage }\end{array}$ \\
\hline $\begin{array}{l}\text { Organisational } \\
\text { skills }\end{array}$ & $\begin{array}{ll}\text { - } & \text { plan objectives } \\
\text { - } & \text { more structured thinking and planning } \\
\text { - } & \text { clarify aims }\end{array}$ \\
\hline More cycling & $\begin{array}{l}\text { - one participant said she would get her bike fixed so she } \\
\text { could ride to school }\end{array}$ \\
\hline Overall project & $\begin{array}{l}\text { - } \quad \text { go about setting their project up in a different way } \\
\text { - implement the new ideas they had got for encouraging } \\
\text { more people to join their group } \\
\text { - } \text { more teamwork and planning }\end{array}$ \\
\hline
\end{tabular}




\section{CONCLUSIONS}

This section examines how the results help us answer our research questions: What benefits can small-scale cycling projects deliver?; and how can their adoption and establishment be supported? This is followed by an overview of conclusions to the work.

\section{What benefits can small-scale cycling projects deliver?}

Summary

We found evidence to suggest that small-scale cycling projects can be important in the following ways:

- They represent a way of engaging a much wider audience with cycling than the conventional approach of promoting cycling as transport, as they are relevant to a range of high priority needs and priorities in many communities, for example crime diversion, activities for young people, training

- They can play a part in creating a supportive culture for cycling

- They are a tool for contributing to community development and social inclusion needs

- They impact on increasing cycling directly

- They offer an important approach to promoting cycling to policy makers

More specifically under this heading we wanted to look at:

- What relevance do they have to cycle promotion generally

- What they can deliver in their own terms

Cycling is a marginal activity in the UK with potential for significant increases. It has the potential to make an important contribution to a sustainable transport system, and hence there is a need to promote and support increased cycling. But why small-scale community cycling initiatives particularly? What can these add to the more usual concentration on cycling for sport, leisure, or transport?

We found a number of answers to this question demonstrating how such initiatives can contribute to cycle promotion generally, and what they can deliver in their own terms:

i) Widening the appeal of cycling

Small-scale community cycling initiatives are established to meet a wide range of existing, locally relevant needs and achieve a wide range of locally relevant aims such as providing activities and engagement for young people, or providing training and skills (as shown in table 5.5). They also deliver a wide range of locally relevant outcomes and outputs (as reported by the projects themselves, and observed during our work), from new facilities, activities and resources, to personal development and crime diversion (as shown in tables 3.5 and 5.16).

The range of people to whom the above mentioned issues are of interest and relevance is much wider than the range to whom cycling as a means of transport or leisure activity is relevant. In addition, the aims that people are addressing with cycling projects and the outcomes achieved are aims and outcomes that are high on the list of priorities for many 
communities, especially in low-income areas, for example training, activities for young people, job creation.

Small-scale community cycling projects therefore show that cycling can be relevant to high priority needs and interests in many communities, to a much greater extent than cycling as transport. They represent a way to promote cycling to a much wider audience.

We have some evidence that once people have been engaged in cycling through such projects, they have become more motivated or confident to increase the amount of cycling that they do outside the project. For example one young person said that she would cycle to school more as a result of attending one of our training courses, and another said that the course had given him more confidence to ride on the roads. One adult leader said that the cycle trip we had taken on the first course had given her more confidence on her bike.

ii) Creating a culture supportive of cycling

If small-scale cycling projects are in place, with accompanying wider use of cycles, this also creates a culture of support for cycling in two distinctive ways:

- the association of cycling with more widely relevant positive social inclusion impacts should mean that cycling is seen as a more positive thing generally

- practical supports for cycling are more likely to be available, for example repair skills, safe cycling training

iii) An effective tool for community development and social inclusion

Small-scale cycling projects can be effective in addressing community development and social inclusion needs.

As tables 3.5 and 5.16 and the Pedal Power case studies (Case studies 5 - 12) show, cycling projects can deliver positive social inclusion outputs and outcomes, for example essential services for young people, and the elderly or disabled, crime diversion, employment. When these projects are set up and run by community groups additional benefits of capacity building and community development result, for example personal development, organisational skills, development of project plans and ideas, as can be seen in the Pedal Power case studies

iv) Direct impact on cycling

More simply, these projects can impact on cycling directly, for example by providing training in safer cycling and providing young people with cycles, as shown in tables 3.5, and the Pilot and the Pedal Power case studies (Case studies 1 -12).

v) Promoting cycling to the policy makers

Cycling is not seen as a very important issue by most policy makers and politicians. Social inclusion on the other hand is a high policy priority. By highlighting the ways in which cycling projects deliver social inclusion outcomes it may be possible to engage more policy level interest. The results of our work so far, and advertisements for a new organisation to develop Bike up your life, have drawn interest by a wide range of organisations. A number of these, for example Transport 2000 and Crime Concern have been interested by the links between social inclusion and cycling that we have been drawing out, as being something they would like their organisation to include in their work. An organisation, and a 
separate, individual involved in lobbying for cycling and sustainable transport have said that they would like to use our results to add to the case for more importance for cycling in policy.

\section{If small-scale cycling projects are worthwhile, how can their adoption and establishment best be supported?}

\section{Summary}

- The fact that small-scale cycling projects can be effective tools for tackling existing community needs is an important angle in promoting cycling projects and engaging local communities in developing them

- Once interested, local communities can need a wide range of different types of support to help them set up cycling projects, from basic information and advice, through training and funding, to consultancy help with specific tasks and ongoing intensive support.

- We present 3 different approaches to providing this support and discuss their relative advantages and disadvantages. Together, these approaches cover most needs that communities encounter when establishing live cycling projects. The approaches are:

- Taking a lead in setting up projects

- Providing basic support to others who are setting up projects

- Providing intensive support to others setting up projects

More specifically under this question we consider:

- What can we say about approaches to promoting this type of action by communities?

- How can we best support communities to set up cycling projects? - What are the pros and cons of different approaches to achieving the development of small-scale cycling initiatives?

\section{Promoting small-scale cycling projects}

Firstly, we need to get people interested in wanting to get involved in and set up cycling projects. There is little if any precedent to guide us here. The vast majority of cycle promotion work is focused on improving infrastructure and safety for cycling, and promotional campaigns to try and encourage more people to cycle.

The 'traditional' approach to cycling promotion - selling the benefits of cycling as a means of transport, and a way of keeping fit and having fun - goes some way towards engaging people. The links to more widely relevant issues that we have emphasised bring an added dimension to this engagement. If cycling projects are sold as effective tools to tackle existing community priorities then communities and individuals who would not otherwise give cycling a second thought, and who are not moved by the 'traditional' selling points of cycling, are much more likely to take notice.

The evidence that we have to back this up is as follows:

- We investigated the aims of people and groups, involved in Bike up your life, wanting to set up cycling projects, and the aims of other projects on the cycling projects database. As table 5.5 and results from the cycling database projects show, the majority of aims of groups wanting to set up cycling projects were non-cycling related. Many of these non- 
cycling related aims were relevant to issues that tend to be high on the list of priorities for many communities, for example providing training and skills, providing youth activities, crime diversion. We had specifically highlighted the non-cycling aspect in advertising the Bike up your life programme, and so we could perhaps expect groups to have applied who responded to this. However cycling was an obviously important part of the programme as well, and we did not have any influence over the projects on the database.

- To clarify properly our combined cycling and social inclusion aims, and to counter the more obvious cycling emphasis of the project, we emphasised the non-cycling, community development angle in our advertising and literature for Bike up your life.

This resulted in a good level of interest. For example our flyer, and a number of pieces included in newsletters, contained the following wording:

"Cycling does not have to be your prime interest - group and community development could be just as important"

We also included examples emphasising training, leisure activities and independence for young people, rather than the cycling aspect.

We based this approach on our initial research and on the need to reach communities that might otherwise have been excluded.

Together, we feel that this evidence supports our theory that cycle projects in low-income communities can be encouraged to develop by drawing out the links to existing needs and interests, even if these are non-cycling related. They indicate that people in these communities are motivated by the types of social inclusion and community development issues that we have drawn out, and that they respond well to a programme that emphasises them.

\section{How can we help it to happen?}

The answer to this question begins with a consideration of the types of support groups need when trying to set up small-scale cycling projects. Following this we can ask how best to meet this need and provide this support. We discuss the approaches we have taken and how they match up to the type of support needed in different circumstances.

\section{Support needed}

The development of new small-scale cycling projects can require a broad spectrum of different things to happen, such as a partner to lead the process, training to help the people involved realise their plans, or a simple piece of practical information. A broad spectrum of different types of support can respond to these needs and help meet them, such as the support organisation taking a lead in bringing a project into existence and finding partners to take it forward, training courses, or information sheets. The support required to realise a new project depends both on the state of development of the project and the existence, and capacity, of a group or organisation to develop and run the new project. 
At the most basic level, support may be needed to bring a project into existence in the first place. This is illustrated by the pilot projects we helped set up in Lewisham where it was our presence wanting to set projects up that led to their inception (see case studies 3 and 4). In a similar way, the existence of a support programme and the promise of funding helped gel a number of groups into action and bring several of the Pedal power projects into existence. In a number of cases the groups involved reported that it had been the arrival of literature advertising the support programme that had led them to take action on what had previously only been an idea at the back of their minds (see, for example, case studies 6 and 9).

Once the idea has been born, there is still a wide range of support that can be needed to realise the project.

At the most extreme end of the spectrum, as illustrated by the pilot projects we helped establish in Hackney and Lewisham, there may be no specific organisation, group or person to take a lead in setting up a new project (see case studies $1-4$ ). In such cases the support needed to establish projects is considerable. The supporting organisation needs to take a lead role in developing the project, building partnerships, and raising funding. They also need to provide specific information (such as where to get insurance for the project) and solve specific problems (such as finding a premises for the project, or deciding what salary scales it should employ at).

When a group or organisation already exists that wants to take a lead in setting up a new project, the supporting organisation will not have to take this role but there is still a wide range of support that will potentially be needed.

At the most involved level the existing organisation / group may want to set up a cycling project but not have a concrete idea of the specific project they want to set up, or the experience of setting up a project before. In this case they will need support in developing a specific idea and in learning how to set up a new project - i.e. they will need help with capacity building such as learning about goal setting, action planning, project management. This scenario is illustrated by some of the Pedal Power groups (see, for example, case studies 6 and 10).

A different group may have a specific idea for a project and be more experienced in setting up projects. In this case they may require help with funding, some specific information, and perhaps some specific training and capacity building, but otherwise are capable of setting up the project themselves (see for example case studies 7 and 9).

Finally, there are the groups who have a specific idea, and the capacity to set up a new project. In these cases they may need help with things like raising funding, or with specific information. Examples here are given by the groups who applied to us for Basic support and who received back support such as: specific information sheets, specific pieces of advice, contacts for other groups, ideas on sources of funding.

The spectrum of support needed is illustrated by what groups applying to Bike up your life asked for. This ranged from general basic information and advice, through specific advice, contacts with others and training, to 'handholding' help with a specific task and ongoing intensive support, as illustrated in more detail in table 5.4. 
How we have provided support, and how this matches with support needs

In the process of this work we have taken 3 distinct approaches to helping establish smallscale cycling initiatives:

- Taking a lead in selling the idea and setting up the projects - The pilot projects

- Advertising that we can help others set up projects and providing Basic support - Bike up your life, Basic support

- Advertising that we can help others set up projects and providing intensive, on-going support to help get the projects established - Bike up your life, Pedal Power

All of these approaches have their advantages and disadvantages. They present a range of responses to the range of types of support needed in getting cycle projects established.

Table 6.1 below shows how the different approaches to supporting project development match the range of needs encountered.

This is followed by comparative summaries of the different approaches to supporting project set-up, and a consideration of the way in which the different approaches impacted on project development (Tables $6.2-4$ ). 


\begin{tabular}{|c|c|c|c|c|}
\hline & & \begin{tabular}{|l} 
Basic \\
support
\end{tabular} & $\begin{array}{l}\text { Pedal } \\
\text { Power }\end{array}$ & \begin{tabular}{|l|} 
Pilot \\
projects
\end{tabular} \\
\hline 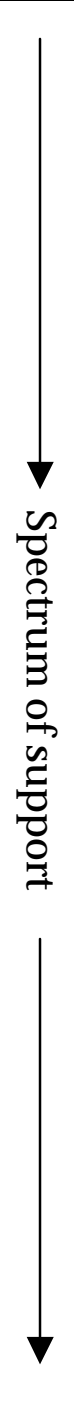 & $\begin{array}{l}\text { General information / advice ideas } \\
\text { Contacts with others } \\
\text { Information and advice on specific issues } \\
\text { Information and advice on organisational } \\
\text { questions } \\
\text { Help involving others / selling idea } \\
\text { Ongoing encouragement and pushing } \\
\text { Training in non-management skills, for } \\
\text { example maintenance } \\
\text { Training in organisational / management } \\
\text { skills } \\
\text { Handholding / outside help for a specific } \\
\text { task } \\
\text { Funding } \\
\text { Ongoing handholding - repeated } \\
\text { involvement } \\
\text { Taking a lead in setting up the project }\end{array}$ & $\nabla$ & $\nabla$ & $\nabla$ \\
\hline
\end{tabular}


Table 6.2 - Compares and contrasts the different approaches to supporting cycling project establishment

\begin{tabular}{|c|c|c|}
\hline Basic support & Pedal Power & Pilot projects \\
\hline $\begin{array}{l}\text { - } \begin{array}{l}\text { Time and resource } \\
\text { cheap }\end{array} \\
\text {. }\end{array}$ & \begin{tabular}{|l} 
time and resource \\
intensive, though \\
less so than pilot \\
projects
\end{tabular} & $\begin{array}{ll}\text { - } & \text { time and resource } \\
\text { intensive }\end{array}$ \\
\hline $\begin{array}{ll}\text { - } & \text { other groups } \\
\text { ultimately } \\
\text { responsible for } \\
\text { project set up }\end{array}$ & \begin{tabular}{|l|} 
other groups \\
ultimately \\
responsible for \\
project set up, but \\
we had some \\
influence \\
\end{tabular} & $\begin{array}{l}\text { we were ultimately } \\
\text { responsible for } \\
\text { project set up }\end{array}$ \\
\hline \begin{tabular}{|l} 
projects set up \\
depended on what \\
groups wanted to do
\end{tabular} & $\begin{array}{ll}\text { - } & \text { projects set up } \\
\text { depended on what } \\
\text { groups wanted to } \\
\text { do, but we had some } \\
\text { influence and could } \\
\text { suggest ideas }\end{array}$ & $\begin{array}{l}\text { possible to develop } \\
\text { projects that } \\
\text { otherwise probably } \\
\text { would not have been } \\
\text { set up }\end{array}$ \\
\hline $\begin{array}{l}\text { - } \text { this approach can } \\
\text { support community } \\
\text { action or 'top down' } \\
\text { action }\end{array}$ & $\begin{array}{ll}\text { - } & \text { supports community } \\
\text { action }\end{array}$ & $\begin{array}{l}\text { - the projects were set } \\
\text { up in a 'top down' } \\
\text { fashion - i.e. lack } \\
\text { community } \\
\text { participation and } \\
\text { development aspect }\end{array}$ \\
\hline $\begin{array}{l}\text { does not actively } \\
\text { contribute to } \\
\text { community } \\
\text { development / } \\
\text { capacity building }\end{array}$ & $\begin{array}{l}\text { actively contributes } \\
\text { to community } \\
\text { development and } \\
\text { capacity building, } \\
\text { where appropriate }\end{array}$ & $\begin{array}{l}\text { did not contribute to } \\
\text { community } \\
\text { development / } \\
\text { capacity building, } \\
\text { but theoretically } \\
\text { could if projects } \\
\text { worked on involved } \\
\text { the community more } \\
\text { in the work }\end{array}$ \\
\hline 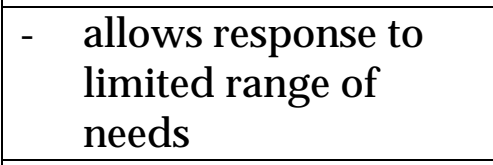 & $\begin{array}{ll}- & \text { allows response to } \\
& \text { large range of needs }\end{array}$ & $\begin{array}{l}\text { theoretically allows } \\
\text { response to any need } \\
\text { in project set up }\end{array}$ \\
\hline \begin{tabular}{|l|} 
limited opportunity \\
to collect \\
information and data
\end{tabular} & $\begin{array}{l}\text { - } \begin{array}{l}\text { allows collection of } \\
\text { much information } \\
\text { and data }\end{array} \\
\end{array}$ & $\begin{array}{l}\text { allows collection of } \\
\text { any information and } \\
\text { data }\end{array}$ \\
\hline
\end{tabular}


Table 6.3 - Scope of the different approaches we took to supporting the development of cycling projects

\begin{tabular}{|c|c|c|c|}
\hline & Basic support & Pedal Power & Pilot projects \\
\hline $\begin{array}{l}\text { Number of } \\
\text { projects } \\
\text { supported }\end{array}$ & $\begin{array}{l}26 \text { (Plus } 3 \text { more } \\
\text { which were too } \\
\text { late to be } \\
\text { included in this } \\
\text { analysis) }\end{array}$ & -8 & -4 \\
\hline Time period & $\begin{array}{l}\text { Over } \\
\text { approximately } 18 \\
\text { months }\end{array}$ & $\begin{array}{ll}- & \text { Over } \\
& \text { approximately } \\
& 18 \text { months }\end{array}$ & $\begin{array}{l}\text { Two over } \\
\text { approximately } \\
4 \text { months; the } \\
\text { other } 2 \text { over } \\
\text { approximately } \\
2 \text { years }\end{array}$ \\
\hline $\begin{array}{l}\text { How the } \\
\text { support was } \\
\text { delivered }\end{array}$ & $\begin{array}{l}1 \text { off written } \\
\text { response, plus } \\
\text { one-off telephone } \\
\text { follow up. Some } \\
\text { also received 1-off } \\
\text { telephone advice }\end{array}$ & $\begin{array}{ll}- & \begin{array}{l}\text { Repeated } \\
\text { telephone } \\
\text { contact and }\end{array} \\
\text { advice } \\
- & \text { Repeated } \\
& \text { written } \\
\text { information } \\
- & \text { Residential } \\
\text { training } \\
\text { courses } \\
- & \text { Group visits }\end{array}$ & $\begin{array}{l}\text { - } \begin{array}{l}\text { Lead role in } \\
\text { developing and }\end{array} \\
\text { securing } \\
\text { funding (all } 4 \\
\text { projects) } \\
\text { - Lead role in } \\
\text { establishing } \\
\text { pilots (2 of the } 4 \\
\text { projects) } \\
\text { - Role in } \\
\text { continued } \\
\text { running and } \\
\text { troubleshooting } \\
\text { (2 of the } 4 \\
\text { projects) }\end{array}$ \\
\hline $\begin{array}{l}\text { Outcomes } \\
\text { (in terms of } \\
\text { 'whole' } \\
\text { cycling } \\
\text { projects) }\end{array}$ & $\begin{array}{l}9 \text { out of } 14 \text { groups } \\
\text { who provided } \\
\text { feedback said that } \\
\text { the support had } \\
\text { had some impact } \\
\text { on their projects }\end{array}$ & $\begin{array}{ll}- & 4 \text { new cycle } \\
& \text { projects } \\
- & 2 \text { existing } \\
& \text { cycle projects } \\
\text { developed }\end{array}$ & $\begin{array}{l}4 \text { new cycle } \\
\text { projects }\end{array}$ \\
\hline
\end{tabular}


Table 6.4 - How different approaches to support impacted on projects they were trying to help

\begin{tabular}{|c|c|c|}
\hline Basic support & Pedal Power & Pilot projects \\
\hline $\begin{array}{l}\text { - Most impacts were } \\
\text { specific and limited, } \\
\text { influencing single } \\
\text { aspects of the } \\
\text { projects, for } \\
\text { example gave } \\
\text { contacts, helped } \\
\text { them secure } \\
\text { funding } \\
\text { - A number of } \\
\text { projects also } \\
\text { reported more } \\
\text { general impacts } \\
\text { having a more } \\
\text { widespread impact } \\
\text { on their projects i.e. } \\
\text { help in focusing } \\
\text { their thinking, } \\
\text { deciding what to } \\
\text { do, or with ideas; } \\
\text { confidence / a } \\
\text { sense of legitimacy }\end{array}$ & $\begin{array}{l}\text { - Some specific and } \\
\text { limited impacts } \\
\text { relating to single } \\
\text { specific aspects of the } \\
\text { projects, for example } \\
\text { specific information, } \\
\text { advice and training } \\
\text { - } \quad \text { Capacity building } \\
\text { support impacting on } \\
\text { the groups' abilities to } \\
\text { set up projects, for } \\
\text { example training in, } \\
\text { and help with, } \\
\text { organisational skills; } \\
\text { help clarifying aims } \\
\text { and developing } \\
\text { funding applications } \\
\text { - Helping encourage the } \\
\text { inception of the project } \\
\text { - Giving time, focus and } \\
\text { impetus for groups to } \\
\text { work on their projects } \\
\text { General widespread } \\
\text { impacts such as } \\
\text { confidence, sense of } \\
\text { legitimacy, } \\
\text { encouragement }\end{array}$ & $\begin{array}{l}\text { - Responsible for } \\
\text { existence of projects } \\
\text { in } 2 \text { of the } 4 \text { pilots, } \\
\text { and catalysing the } \\
\text { set up in the other } 2 \\
\text { - Taking lead role in } \\
\text { developing project } \\
\text { proposals and } \\
\text { securing funding } \\
\text { - Responsible for } \\
\text { negotiating with } \\
\text { and involving } \\
\text { partners } \\
\text { In } 2 \text { of the pilots we } \\
\text { were responsible } \\
\text { for taking a lead } \\
\text { role in the actual } \\
\text { setting up and } \\
\text { establishment of the } \\
\text { projects, and a } \\
\text { troubleshooting role } \\
\text { in their ongoing } \\
\text { running }\end{array}$ \\
\hline
\end{tabular}




\section{Overview}

Overall we can conclude:

1) There is widespread interest in cycling projects and activities at the community level, and the idea of cycling projects tends to meet with interest and enthusiasm.

2) There is a wide range of ideas among existing small scale cycling projects, and some very imaginative and innovative projects taking place.

3) Youth, local authority and voluntary services are keen to get involved in cycling projects.

4) The link between small-scale cycling projects and social inclusion can be strong. Such projects represent a useful tool for communities wanting to address a range of needs in their areas, such as crime diversion, training, youth activities, and flexible local transport. They can successfully draw together a wide range of different issues, for example training, job creation, road safety, recycling, health and personal development: in a youth cycle recycling project. Additionally, when communities get involved in developing their own local cycling projects the process of doing so contributes to capacity building and community development.

5) This link to social inclusion is appealing to communities motivated by immediate needs and concerns, which, in our experience, will rarely be cycling. By emphasising the solutions that cycling projects can deliver to existing concerns, their relevance and interest will be broadened. This can be exploited as one element of the approach to promoting and increasing cycling generally, and getting people interested in setting up cycling projects, more specifically.

6) Small-scale cycling projects do work - they can practically deliver on a range of linked social inclusion, environmental, and cycling outcomes.

7) Most of the problems that groups meet in developing small-scale cycling projects are relatively easy to overcome given the right support.

8) A wide range of different types of support can be needed to help others set up new cycling projects, from basic information to 'handholding', funding and capacity building. All of these needs can be met. We have developed and tested three different approaches to doing so and have discussed the applicability of each. This should help practitioners in delivering support themselves.

9) The significant expansion of cycling project activity in the UK has the potential to contribute to several government and non-government policy agendas, including: sustainable transport; sustainable development; the Social Exclusion Unit's agenda for neighbourhood renewal which calls for integrated and sustainable approaches to the problems of the worst housing estates; community development and capacity building.

10) The focus on links between cycling and more widely relevant social inclusion issues that we have studied here adds an important new dimension to traditional approaches to promoting cycling. However there is still much work that could usefully be done in applying and expanding this approach to the direct issue of cycling as transport. A wider follow up could concentrate on significantly increasing cycling as a transport mode in low-income areas, with an emphasis on links to social inclusion and sustainable transport. 


\section{PART II - THE CASE STUDIES}

\section{The pilot project case studies}

The Hackney pilots

Lewisham is one of the top 5 most deprived local authority districts according to the 1998 Index of Local Deprivation ('Bringing Britain Together', SEU, 1998). Groundwork Hackney $(\mathrm{GWH})$, a local Trust of the national environmental regeneration charity, was the principal partner for our work in this borough. They had already been involved in developing ideas and proposals around cycling in Hackney. After initial negotiations (beginning in approximately August 1998) we decided to work on two projects with them.

After we had written the detailed project proposals and raised the funding for each project, we handed them over to GWH to deliver as project managers (for which they received a percentage fee from the budget), overseen by a steering group representing the project partners in each case. From this point we had no official involvement in these projects.

\section{Case study 1 - Hackney cycle delivery project}

This project was to offer deliveries and a limited (1-day/week) taxi service for New Islington and Hackney Housing Association (NIHA) sheltered housing tenants. In development the taxi service part of the plan was dropped and it ended up just running a delivery service for groceries and other small items.

Summary of project progress

\begin{tabular}{|c|c|}
\hline & $\begin{array}{l}\text { - GWH unsuccessfully apply for European funding for } \\
\text { community cycle delivery business } \\
\text { - } \quad \text { GWH scale down idea and approach NIHA } \\
\text { - }\end{array}$ \\
\hline August 1998 & $\begin{array}{l}\text { - LSE Housing cycling project began initial negotiations with } \\
\text { GWH } \\
\text { - Agree LSE Housing cycling project to produce detailed } \\
\text { project proposal to raise funding }\end{array}$ \\
\hline October 1998 & $\begin{array}{l}\text { - } \quad \text { Proposal produced } \\
\text { - } \quad \text { The Ashden Trust and NIHA agree to fund } 6 \text { months pilot } \\
\text { - Project handed over to GWH to deliver as project managers, } \\
\text { and steering group }\end{array}$ \\
\hline Beginning 1999 & $\begin{array}{l}\text { - Partners agree to tender pilot work to existing cycle delivery } \\
\text { organisation }\end{array}$ \\
\hline April 1999 & $\begin{array}{l}\text { - } \quad \text { E-mission control win tender to deliver pilot } \\
\text { - GWH take a back seat and NIHA and E-mission control take } \\
\text { lead roles }\end{array}$ \\
\hline Late 1999 & - $\quad$ Service starts running \\
\hline
\end{tabular}




\begin{tabular}{|l|l|}
\hline July 2000 & $\begin{array}{l}\text { Project partners produce report from pilot phase of project, } \\
\text { and proposal to run for another } 6 \text { months development phase, } \\
\text { resulting in a 3-5 year business plan } \\
-\end{array}$ \\
The Ashden Trust and NIHA are considering the proposal
\end{tabular}

\section{Outcomes}

- New service established for sheltered housing residents, assessed as being much needed by the scheme organisers

- $\quad$ The pilot delivered a service to 15 clients in NIHA sheltered housing schemes

- There is a waiting list of people wanting to use the service

- Personal contact with clients, along with delivery service, reported to 'make a huge difference' to clients' lives

- Before the service started many of the users had had to rely on friends or family to do their shopping and some had had experience of unsuccessful home care

- The project also supplied an internal mail delivery service for the sheltered housing schemes being served within NIHA. This was delivered with no disruption to the main service, and has led to negotiations to extend this service and start making some income for the project.

- Lessons learned about clients' needs, leading to development and improvement of service

- Funding levered into area, and freed from pots allocated to the area

- 1 part-time rider and 1 part-time co-ordinator employed

\section{Case study 2 - Hackney cycle recycling project - which became a cycle training project} This project originally planned to run a cycle recycling workshop on a housing estate in Hackney, in conjunction with two local residents. Unfortunately this project did not come to fruition and a different one was developed and run. The actual pilot project involved a 10-week programme of cycle maintenance and on road safe cycling training at 3 adventure playgrounds in the borough.

\section{Summary of project progress}

\begin{tabular}{|c|c|}
\hline & $\begin{array}{l}\text { - GWH were thinking about the idea of setting up a cycle } \\
\text { recycling project and had approached the police about } \\
\text { donating cycles } \\
\text { - Independently of this a local tenant approached GWH } \\
\text { wanting help to establish a cycle recycling project } \\
\text { - Tenant had collected some old cycles and had some young } \\
\text { people interested }\end{array}$ \\
\hline August 1998 & $\begin{array}{l}\text { - LSE Housing cycling project began initial negotiations with } \\
\text { GWH } \\
\text { - Agree LSE Housing cycling project worker to produce } \\
\text { detailed project proposal to raise funding }\end{array}$ \\
\hline $\begin{array}{l}\text { August - } \\
\text { October } 1998\end{array}$ & $\begin{array}{l}\text { - LSE Housing cycling project worker meets and consults } \\
\text { with local resident, estate youth worker and Tenants and } \\
\text { Residents association } \\
\text { - Proposal produced }\end{array}$ \\
\hline
\end{tabular}




\begin{tabular}{|c|c|}
\hline October 1998 & $\begin{array}{l}\text { - Funding for } 6 \text { months pilot secured from the Ashden Trust } \\
\text { and GWH Single Regeneration Budget for the estate } \\
\text { - Project handed over to GWH, as project managers, and } \\
\text { steering group }\end{array}$ \\
\hline $\begin{array}{l}\text { November } \\
1998- \\
\text { Spring } 1999\end{array}$ & $\begin{array}{l}\text { - Other issues arising on the estate and with partners mean } \\
\text { that project is abandoned by GWH } \\
\text { - New project developed and new partners secured for } \\
\text { training sessions in adventure playgrounds } \\
\text { - } \quad \text { Funding from Ashden Trust transferred to new project } \\
\text { - SRB funding cannot be transferred because playgrounds } \\
\text { not within the right area }\end{array}$ \\
\hline $\begin{array}{l}\text { March - May } \\
2000\end{array}$ & $\begin{array}{l}\text { - Weekly playground sessions begin } \\
\text { - } \quad \text { Sessions run } \\
\text { - } \quad \text { Final session involves all young people from all } \\
\text { playgrounds in a mass ride to a local cycle track }\end{array}$ \\
\hline $\begin{array}{l}\text { May - } \\
\text { August } 2000\end{array}$ & $\begin{array}{l}\text { - GWH include cycle maintenance activities in their summer } \\
\text { scheme programme } \\
\text { - GWH apply to local business for funding to run a similar } \\
\text { scheme for young people with disabilities } \\
\text { - GWH plan to produce report from pilot and proposal to } \\
\text { repeat and expand the scheme }\end{array}$ \\
\hline
\end{tabular}

\section{Outcomes}

- New activities for young people attending adventure playgrounds

- Approximately 20 young people took part over the period of the programme at each playground (Total of approximately 60 young people for the whole programme).

- At each site 4 or 5 regular attendees emerged over the whole programme.

- 26 young people took part in the final group trip to the cycle circuit

- The racial mix of young people attending the sessions was believed to be representative of the area by those running the project.

- Both GWH and Cycle Training reported the programme to have been very successful

- Cycle training reported that 'feedback from all involved ...has been overwhelmingly positive. The sessions were very successful and enjoyed a high level of enthusiasm from participants.'

- GWH commented that it had been a '...highly successful project' and felt that it could be easily replicated

- All 3 adventure playgrounds that took part in the programme have said that they would like to run more of the same.

- Other adventure playgrounds in Hackney have said that they would like to run the programme, and so have a number of after school clubs.

- 12 cycles recycled / repaired to roadworthiness

- 4 recycled cycles donated to young people attending the sessions

- 8 recycled cycles kept by playgrounds as a communal resource for young people

- Funding levered into area

- In kind contribution of worker time from playgrounds 
- 6 cycle trainers employed

\section{The Lewisham pilots}

In Lewisham we decided to work on a single housing estate, Downham. This is a very large housing estate (26,000 residents), approximately 1 mile across. Lewisham is one of the top 15 most deprived local authority districts according to the 1998 Index of Local Deprivation ('Bringing Britain Together', SEU, 1998). The principal partners were the Lewisham sustainable transport officer and Downham Pride (DP), the Downham SRB project.

The work in Lewisham contrasted with that in Hackney in that we (LSE Housing cycling project) not only took the lead on working up detailed project proposals and raising funding for the projects, but also remained closely involved through the actual physical setting up of the pilots. This was necessary as there was no partner in the area willing to take this role. We have also continued to have involvement, to a lesser extent, through the running of the pilots and their development beyond the pilot stage, again because of the lack of any lead partner to do this 'in situ'.

\section{Case study 3 - Downham cycle taxi project}

This project aimed to provide a local cycle taxi service for elderly people on the estate, following consultation that had shown that residents suffered from inadequate bus and special transport services.

Summary of project progress

\begin{tabular}{|c|c|}
\hline & $\begin{array}{l}\text { - Consultation with elderly people on Downham highlights need for } \\
\text { better local transport options } \\
\text { - Lewisham borough council sustainable transport officer thinking of } \\
\text { cycle taxi idea for shopping centres } \\
\text { - LSE Housing cycling project contact with sustainable transport } \\
\text { officer leads to development of cycle taxi idea for Downham }\end{array}$ \\
\hline July 1998 & $\begin{array}{ll}\text { - } & \text { LSE Housing cycling project worker meets with head of DP } \\
\text { - } & \text { LSE Housing cycling project worker agrees to develop detailed } \\
& \text { proposal for pilot project to raise funding }\end{array}$ \\
\hline $\begin{array}{l}\text { July - } \\
\text { October } \\
1998\end{array}$ & $\begin{array}{l}\text { - Meet with Downham Elderly Health Development Project (DEHP) } \\
\text { worker } \\
\text { - } \quad \text { Develop proposal }\end{array}$ \\
\hline $\begin{array}{l}\text { October } \\
1998\end{array}$ & $\begin{array}{l}\text { - } \text { Submit proposal for funding to DP and the Ashden Trust } \\
\text { - } \text { DP decline funding } \\
\text { - } \quad \text { Further research and development of proposal }\end{array}$ \\
\hline $\begin{array}{l}\text { November } \\
1998\end{array}$ & $\begin{array}{l}\text { - Proposal re-submitted and DP agree to funding } \\
\text { - } \quad \text { Ashden Trust agree to funding and Lewisham Sustainable } \\
\text { Transport Officer contributes funding from cycling budget }\end{array}$ \\
\hline $\begin{array}{l}\text { December } \\
1998\end{array}$ & $\begin{array}{l}\text { - No partner available to take project forward and so LSE Housing } \\
\text { cycling project continues to take the lead role }\end{array}$ \\
\hline
\end{tabular}




\begin{tabular}{|c|c|}
\hline April 1999 & $\begin{array}{l}\text { - Project stall because no premises can be found } \\
\text { - } \quad \text { Premises still not available } \\
\text { - } \text { Deadline set to sort problem out one way or another }\end{array}$ \\
\hline May 1999 & $\begin{array}{l}\text { - Premises found and confirmation that project could use it received } \\
\text { - Sustainable Transport Officer agrees to hold project budget and } \\
\text { employ staff } \\
\text { - Lewisham Personnel Services agree to help with recruitment and } \\
\text { appointment of staff } \\
\text { - Posts advertised }\end{array}$ \\
\hline June 1999 & $\begin{array}{ll}\text { - } & \text { Project co-ordinator interviewed and appointed } \\
\text { - } & \text { Cycles ordered } \\
\text { - } & \text { Riders recruited }\end{array}$ \\
\hline July 1999 & - Project starts running \\
\hline $\begin{array}{l}\text { August } \\
1999\end{array}$ & $\begin{array}{l}\text { - Official project launch with local dignitaries } \\
\text { - } \quad \text { Pieces in press and flyers distributed }\end{array}$ \\
\hline $\begin{array}{l}\text { December } \\
1999\end{array}$ & $\begin{array}{l}\text { - Project purchases trailer and starts running home delivery service as } \\
\text { well a taxi service } \\
\text { - Taxi service running at approximately capacity } \\
\text { - } \quad \text { Short delivery contract with local shop } \\
\text { - } \quad \text { Report of pilot period produced and continuation funding applied } \\
\text { for } \\
\text { - } \quad \text { Continuation funding secured (after initial rejection) from DP } \\
\text { - Continuation funding secured from the Ashden Trust } \\
\text { - } \quad \text { Advertising space on the cycles sold to a local firm }\end{array}$ \\
\hline $\begin{array}{l}\text { February } \\
2000\end{array}$ & - User consultation about membership and changes in service charges \\
\hline April 2000 & $\begin{array}{l}\text { - Membership and new charges introduced } \\
\text { - Immediate fall in number of users, quickly reversed and previous } \\
\text { levels of use recovered } \\
\text { - Charitable status applied for }\end{array}$ \\
\hline $\begin{array}{l}\text { April - } \\
\text { August } \\
2000\end{array}$ & $\begin{array}{l}\text { - Project set up their own independent bank account } \\
\text { - } \quad \text { Project starts operating independently of Lewisham council } \\
\text { - } \quad \text { Trial delivery contract with local chemist } \\
\text { - } \quad \text { Personal delivery service to elderly and housebound } \\
\text { - } \quad \text { Publicity drive } \\
\text { - }\end{array}$ \\
\hline
\end{tabular}




\section{Outcomes}

- Two new services for people on Downham estate responding to established need

- Cycle taxi service has averaged between 70 - 80 fares (journeys carrying one or 2 passengers) / week - this is approaching capacity for the two vehicles

- Approximately 70\% of passengers are elderly or disabled

- 3 local people employed as drivers, 1 full, and the others part -time. These people were previously unemployed

- 1 other person employed full time

- Project had approximately 30 users who had become members in May 2000

- As of May 2000 the project carried out home deliveries for 6 regular customers

- User response to the service has been very positive: Users highly value the service and appreciate the personal door-to-door service

- A number of users are heavily reliant on the services and there are trips and things they can now do that they just couldn't before. In a survey returned by 16 users, 6 said that the services meant they could make journeys that they hadn't previously been able to

- For many users the service is the means for the only time they spend out of their homes

- The home delivery service provides important social contact for some isolated users, for example two of the regular users of the delivery service see only one other person than the person doing deliveries

- The service provides positive contact between young and elderly people, and in an area where racism is a problem, the fact that two of the riders are black women adds to this positive interaction

- The service has sold advertising space on the cycles for $£ 3,000$ per annum

- Positive lessons and evidence to promote the replication of this project elsewhere

- Income generated through membership fees and payment for services

- Funding levered into area, and freed from pots allocated to the area

- Positive publicity in local press

\section{Case study 4 - Downham cycle recycling project}

This project aimed to set up and run a weekly cycle recycling workshop for young people on Downham, giving them an engaging activity, training and the opportunity to get a new cycle. The idea for this project arose when we mentioned the type of project in passing to the head of DP, and she said that it fitted with a lot of their aims.

Summary of project progress

\begin{tabular}{|c|c|}
\hline July 1998 & $\begin{array}{l}\text { LSE Housing cycling project worker meets with head of DP and } \\
\text { idea was born } \\
\text { - LSE Housing cycling project worker agrees to develop detailed } \\
\text { proposal for pilot project to raise funding }\end{array}$ \\
\hline $\begin{array}{l}\text { July - } \\
\text { October } \\
1998\end{array}$ & $\begin{array}{l}\text { - Meetings with Lewisham Borough Council Youth Services and } \\
\text { consultation with youth workers in the two youth clubs on } \\
\text { Downham }\end{array}$ \\
\hline $\begin{array}{l}\text { October } \\
1998\end{array}$ & $\begin{array}{l}\text { - Proposal finished and submitted for funding } \\
\text { - } \quad \text { Funding secured from DP and the Ashden Trust } \\
\text { - } \quad \text { LSE Housing cycling project agrees to continue taking lead role }\end{array}$ \\
\hline
\end{tabular}




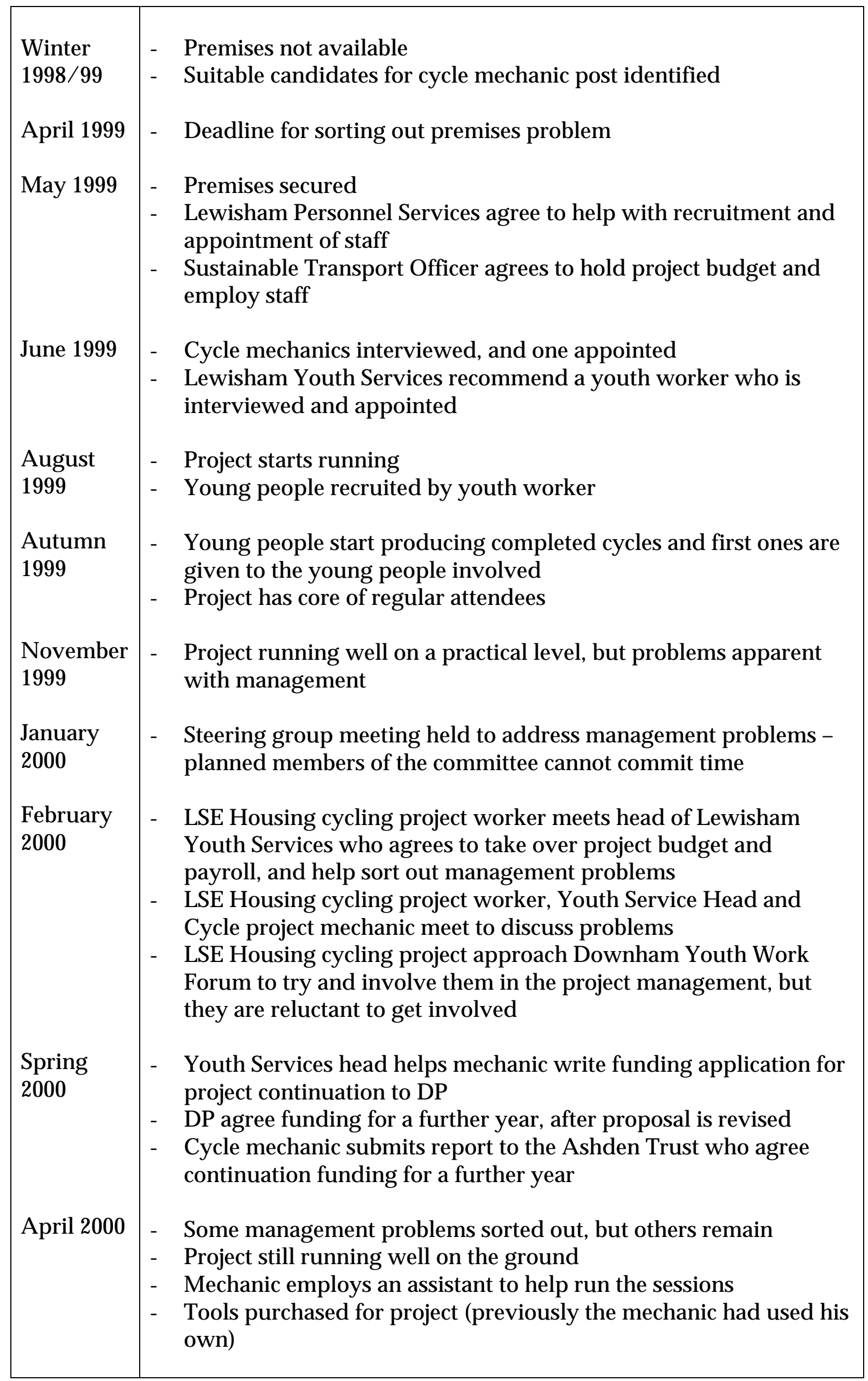




\begin{tabular}{|l|l|}
\hline July 2000 & $\begin{array}{l}\text { Numbers of young people attending the project have risen to such } \\
\text { a level that they had to be split into two groups, each attending } \\
\text { every on alternate weeks }\end{array}$ \\
$-\begin{array}{l}\text { Problems with project management still present, especially lack of } \\
\text { steering group } \\
\text { LSE Housing cycling project still involved in trying to solve } \\
\text { management problems }\end{array}$ \\
\hline
\end{tabular}

Outcomes

- Totally new activity and facility for young people on the estate

- Response to the project by young people has been good with numbers attending exceeding capacity for one session, and necessitating running two alternating groups

- The youth worker and others have reported that some of the young people engaged by the project are difficult, excluded, or at risk, and are not being engaged by any other existing youth provision

- Cycles recycled and returned to use

- Young people receiving new cycles in return for their work

- Young people learning new skills

- Funding levered into area, and freed from pots allocated to the area

- Three people employed by the project

- Positive publicity in local press 


\section{The Pedal Power group case studies}

\section{Case study 5 - Benwell Bikers}

Summary of key aspects of progress

\begin{tabular}{|c|c|}
\hline 1997 & - Benwell Bikers formed \\
\hline 1998 & $\begin{array}{ll}\text { - } & \text { Regular club running } \\
\text { - } & \text { Won grants for safety equipment and map }\end{array}$ \\
\hline 1999 & $\begin{array}{l}\text { - Problems with attendance. No longer running as such a regular } \\
\text { club }\end{array}$ \\
\hline April 1999 & - Applied to Pedal Power with aim of solving this problem \\
\hline May 1999 & $\begin{array}{l}\text { - Attended Pedal Power course and drew up action plan } \\
\text { - Carried out promotion drive and started holding weekly meetings } \\
\text { again }\end{array}$ \\
\hline $\begin{array}{l}\text { June - } \\
\text { September } \\
1999\end{array}$ & $\begin{array}{l}\text { - } \quad \text { New influx of young people } \\
\text { - } \quad \text { city to do new rides } \\
\text { - Cycle maintenance sessions } \\
\text { - } \quad \text { Trainee worker assigned to help main worker run the club } \\
\text { - Apply for small Pedal Power grant }\end{array}$ \\
\hline $\begin{array}{l}\text { November } \\
1999\end{array}$ & $\begin{array}{ll}\text { - } & \text { Attend second training course } \\
\text { - } & \text { Awarded small grant (from Pedal Power) }\end{array}$ \\
\hline $\begin{array}{l}\text { December } \\
1999\end{array}$ & $\begin{array}{l}\text { - A relative of one of the key young people steels a cycle from the } \\
\text { project }\end{array}$ \\
\hline $\begin{array}{l}\text { February } \\
2000\end{array}$ & - More difficulty with attendance \\
\hline April 2000 & $\begin{array}{ll}\text { - } & \text { Joined forces with local BMX track worker } \\
\text { - } & \text { Recruitment drive } \\
\text { - } & \text { Planning Easter cycle trip }\end{array}$ \\
\hline June 2000 & $\begin{array}{ll}\text { - } & \text { New lot of young people involved } \\
\text { - } & \text { Taster day including cycle activities } \\
\text { - } & \text { Planning cycle trips and activities at a local festival } \\
\text { - } & \text { Original young people had drifted away from the club }\end{array}$ \\
\hline
\end{tabular}

\section{Outcomes}

- Young person receiving increased confidence and self-esteem through attending training course and involvement with the project. He had been 'a bit of a tearaway' at 
school but had really engaged with the cycle club and would help other young people fix their bikes. He appeared in his school magazine when he went on the course.

- Project continued to persevere through difficult periods, and kept running

- Project developed

- Workers received skills and organisational training

- Involvement in project contributes to training for workers

- Providing activities for young people in the area

- Opportunities for young people to explore their area and access the local countryside

- Cycle proficiency training for young people

- Cycle maintenance training and assistance for young people

- Young peoples' cycles made safer

- Safety equipment provided for young people

- Funding brought into the area (see details below)

\section{Pedal Power's role}

- We have awarded them a small grant of $£ 1560$ to cover: worker time; hire of premises; cycle maintenance training sessions; and the hire of a van to transport young people and cycles out of Newcastle for cycle rides

- We have put them in touch with other groups involved in cycling locally

- We helped them write an action plan at the first course that meant they went back to their base with a new boost for the project. The action points helped them get renewed interest and energy into their group

- The second course gave them an opportunity to plan their activities until the end of the year

- They received training that will help them control and manage groups of young people better on their rides

- The second training course contributed to personal development for the young person that they brought with them. Participating on the course gave him new skills and in his own words:

'gives me more confidence to go and ride my bike on the road'

\section{Case study 6 - The Brook club}

Summary of key aspects of progress

\begin{tabular}{|l|ll|}
\hline April 1999 & $\begin{array}{l}\text { Arrival of Bike up your life literature led to their taking action an idea } \\
\text { they had been thinking about and they applied for a place on Pedal } \\
\text { Power }\end{array}$ \\
May 1999 & $\begin{array}{l}\text { - } \\
-\end{array}$ \\
Sedal Power training course - worker with two young people & Started work on an action plan \\
November \\
$\begin{array}{l}\text { - Secured 'in kind' donation of a workshop space } \\
\text { - Second training course }\end{array}$ \\
$\begin{array}{l}\text { December } \\
1999\end{array}$ & $\begin{array}{l}\text { Secured funding for youth worker and tools, donations of old cycles } \\
\text { from local residents and the police, and publicity }\end{array}$ \\
\hline
\end{tabular}




\begin{tabular}{|l|ll|}
\hline & - & Applied for Pedal Power Small grant \\
March & $-\quad$ Received Pedal Power grant \\
2000 & $-\begin{array}{l}\text { Launch }- \text { false start! - original young people no longer able to be } \\
\text { involved }\end{array}$ \\
$\begin{array}{l}\text { August } \\
2000\end{array}$ & $\begin{array}{l}\text { Staffing crisis, but light at end of tunnel - SRB funding and } \\
\text { recruitment in progress } \\
\text { Young people keen to get started }\end{array}$ \\
\hline
\end{tabular}

Outcomes

- Two young people involved from the beginning in setting up a project in their community

- Two young people and one worker received training in practical and organisational skills

- Group prompted to turn an idea into reality, and given a realistic chance to do so

- New facility for young people and the community in the area

- Funding ('in kind' and actual) brought into the area

- Cycles received from local residents and police

- Positive publicity for the group, area and young people

Pedal Power's role

- Gelling them into action and making an idea reality

- Giving credence to the project has helped get support from others, motivate the people involved and lever in funding

- Funding for their secure tool storage (approximately £600)

- Valuable time out to focus and work on project

- Opportunities for ideas exchange and mutual support from other groups

- Practical skills - especially in planning and managing

- Personal development for the young people involved

- The lead worker described Bike up your life as 'an amazing chance to get something sorted'

and 'it has certainly benefited us'

\section{Case study 7 - Community links}

Summary of key aspects of progress

\begin{tabular}{|l|ll|}
\hline April 1999 & - & Applied for a place on Pedal Power \\
May 1999 & - & $\begin{array}{l}\text { Pedal Power training course }- \text { trainee worker plus } 2 \text { young } \\
\text { people }\end{array}$ \\
Sept 1999 & $-\begin{array}{l}\text { Simplified plans and started work on an action plan } \\
\text { - }\end{array}$ & $\begin{array}{l}\text { Secured funding for personal achievement awards } \\
-\end{array}$ \\
& $-\begin{array}{l}\text { Secured funding towards project start up } \\
\text { Applied for Pedal Power small grant }\end{array}$ \\
\hline
\end{tabular}




\begin{tabular}{|l|l|}
\hline $\begin{array}{l}\text { November } \\
1999\end{array}$ & - Second training course \\
$\begin{array}{l}\text { September } \\
1999-\end{array}$ & $-\begin{array}{l}\text { Work on grant application, and clarifying and developing } \\
\text { February } \\
2000\end{array}$ \\
$\begin{array}{l}\text { February } \\
2000\end{array}$ & $-\quad$ Received Plans \\
\hline
\end{tabular}

Outcomes

- Funding brought in for the project

- Considerable 'in kind' support secured for the project

- Ex-project participant, trainee worker, received skills and organisational training and experience of process of setting up a project

- Project plans clarified and revised

- Workers receiving training to deliver cycle proficiency training and lead young people on and off road

- Young people receiving cycle proficiency training

- Young people taking regular exercise through training for sponsored cycle ride

- New resources, facilities and activities for young people involved in community links and other groups

\section{Pedal Power's role}

- We awarded them a small grant of $£ 2849.51$ for purchasing cycles, tools and spares, and for hiring premises

- We helped the young leader involved in the project start work on an action plan on the first course

- The trainee worker who attended the courses found them useful

- Some specific information we provided was useful

- Helped clarify and revise plans

- Helped them develop their funding application for a Pedal Power small grant

\section{Case study 8_- Focus Senior Club}

Summary of key aspects of progress

\begin{tabular}{|c|c|}
\hline & $\begin{array}{l}\text { - New paid manager of youth centre } \\
\text { - Parent volunteers join and re-invigorate youth centre } \\
\text { - Parent volunteer attempts to set up project but fails due to lack of } \\
\text { support and funding }\end{array}$ \\
\hline April 1999 & - Apply for a place on Pedal Power \\
\hline May 1999 & $\begin{array}{l}\text { - Pedal Power training course - Volunteer worker plus } 2 \text { young people } \\
\text { - Started work on an action plan }\end{array}$ \\
\hline
\end{tabular}




\begin{tabular}{|c|c|}
\hline $\begin{array}{l}\text { Summer } \\
1999\end{array}$ & $\begin{array}{l}\text { - Pedal Power supplies written information, and support and advice on } \\
\text { writing a funding application } \\
\text { - Volunteer worker attends mountain bike leader course, and gains } \\
\text { qualification } \\
\text { - Volunteer worker starts training another volunteer and youth workers } \\
\text { for same qualification }\end{array}$ \\
\hline $\begin{array}{l}\text { August } \\
1999\end{array}$ & $\begin{array}{l}\text { - Receive small grant from local authority youth service } \\
\text { - Apply for a Pedal Power small grant } \\
\text { - Make contact with British Cycling Federation (BCF) and are offered } \\
\text { support }\end{array}$ \\
\hline $\begin{array}{l}\text { October } \\
1999\end{array}$ & - Awarded Pedal Power small grant \\
\hline $\begin{array}{l}\text { November } \\
1999\end{array}$ & - Second training course - work on publicity material \\
\hline $\begin{array}{l}\text { December } \\
1999\end{array}$ & $\begin{array}{l}\text { - Open project bank account } \\
\text { - Start work on secure cycle storage space } \\
\text { - Start work on funding bid to National Lottery Millennium Awards } \\
\text { with BCF and Pedal Power support } \\
\text { - Volunteer worker starts taking young people out on off-road cycle } \\
\text { rides }\end{array}$ \\
\hline $\begin{array}{l}\text { February } \\
2000\end{array}$ & $\begin{array}{l}\text { - Volunteer worker attends BCF cycle skills trainer's training course } \\
\text { - Pedal Power help with writing support letter to cycle manufacturers } \\
\text { - Contact with another Pedal Power group and plans for an exchange }\end{array}$ \\
\hline April 2000 & $\begin{array}{l}\text { - } \text { Receive Millennium Award grant } \\
\text { - Start planning cycle recycling activities, and generate support from } \\
\text { local authority and police } \\
\text { - Volunteer worker starts expedition leader training } \\
\text { - Plan summer cycling activities }\end{array}$ \\
\hline July 2000 & 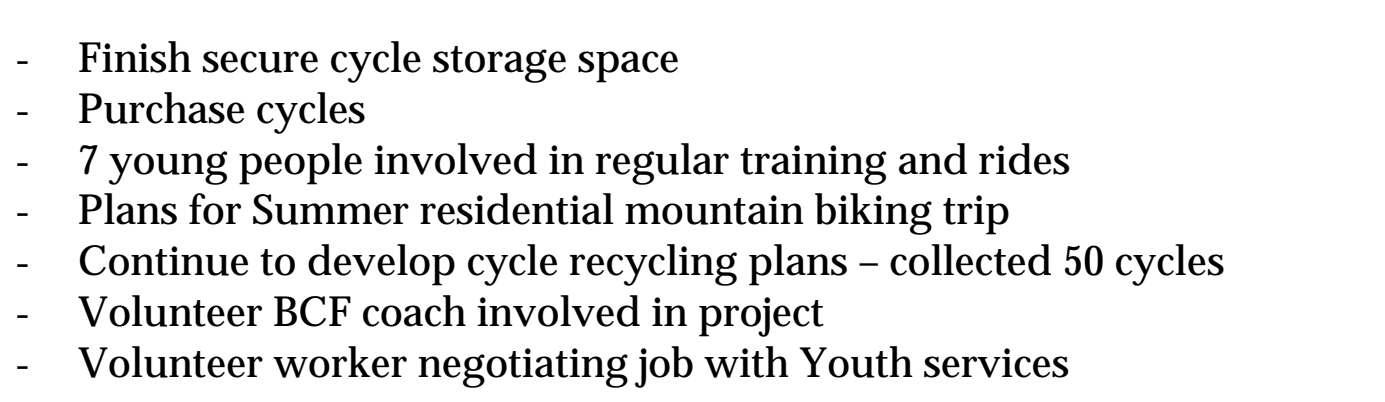 \\
\hline $\begin{array}{l}\text { August / } \\
\text { September } \\
2000\end{array}$ & $\begin{array}{l}\text { - Residential mountain biking trip } \\
\text { - } \text { Group takes part in sponsored ride from London to Brighton } \\
\text { - } \quad \text { Volunteer worker accepts full time youth worker job at the centre } \\
\text { - }\end{array}$ \\
\hline
\end{tabular}




\section{Outcomes}

- Secured total funding of $£ 7015$ from three different sources for cycles, equipment and residential cycle trips

- Volunteer worker received training in practical and organisational skills and personal development, and training and qualifications in cycle leadership

- Work on this project contributed to the volunteer worker who set it up negotiating and accepting a full time paid job as a youth worker

- Young people received training and personal development through involvement with the project and attending training courses

- New activities for young people in an area where there is very little for them to do

- New resources for the youth centre and young people

- Residential away trips for young people

- Another volunteer and youth workers receiving training and qualifications

- Involvement in sponsored cycle ride

- New activities and development for project planned

- Support for new plans secured

- Old cycles collected

\section{Pedal Power's impact}

- They said that we have been an important source of support and backup for them in setting up the project. We have given a focus and sense of reality to getting the project up and running. We have provided support and backup where none was available from the local youth services. The fact that we have been here to provide funding and support / backup means that they have been able to realise their plans. The volunteer worker involved said that we helped

\section{'turn a dream into reality'}

- We have awarded them a small grant worth $£ 2675$

- We have provided advice, including for writing a proposal for getting wider support for their project

- Support and advice with grant applications

- We have provided a sense of identity (including a logo and headed paper) with something bigger that has helped them feel supported and get support from other sources

- They feel confident that they will be able to contact us if they need more help in the future

- We have provided an opportunity for young people from the project to come away from their usual environment and experience something new on the courses

- Training for volunteer worker and young people

\section{Case study 9 - Landport Community Centre}

Summary of key aspects of progress

\begin{tabular}{|l|ll|}
\hline April 1999 & - & Applied for a place on Pedal Power \\
May 1999 & - & $\begin{array}{l}\text { Pedal Power training course - Worker plus 1 young person } \\
-\end{array}$ \\
July 1999 & $\begin{array}{l}\text { Started work on an action plan } \\
\text { Original worker no longer involved - plans to involve youth } \\
\text { worker }\end{array}$ \\
\hline
\end{tabular}




\begin{tabular}{|l|ll|}
\hline & - & Plans developed \\
& - & Discussion with users reveals previously unrealised need \\
& - & Link with local authority cycling officer \\
October & Applied for Pedal Power small grant \\
1999 & - & Received Pedal Power grant \\
& - & Plans further developed \\
- & Agreement with Brook club \\
December & - & Link established with local adventure playground \\
1999 & - & Premises secured as 'in kind' donation \\
March 2000 & - & Dedicated time from youth worker to work on project \\
& - & Secured funding for cycle racks from local authority \\
& - & Action proup of young people established \\
& $-\quad \begin{array}{l}\text { Cycle project included in job description for new youth } \\
\text { worker }\end{array}$ \\
\hline
\end{tabular}

Outcomes

- Worker receiving training in organisational skills and more confidence in her abilities

- Funding brought into area

- New facilities - cycle racks

- New activities for young people

- New resources for the community - cycles

- Young people involved in planning and setting up the project

- In kind support received for premises and as help with maintenance and advice.

- Previously unrealised need for facilities disclosed and met

- Plans for project developed and expanded

- Plans for new project offshoot developed

- Links made with other local group

- Contribution to developing youth committee and provision in the area

\section{Pedal Power's role}

- We have awarded them a small grant of $£ 1129.60$ for cycles, tools, locks and safety equipment

- The lead worker had had a personal idea about doing a cycle project 'for years' and seeing our literature helped gel him into action

- They said that the written information we have sent out to them has been useful

- They feel that we will be available to support them as and when they come across problems in setting up and running / they appreciate the fact that we are at the end of a telephone if they ever need help

- They were ready to apply for a small grant sooner than we made them available, as we were holding back until the groups had gone through initial planning stages. They now feel however that this delay was beneficial as it meant that they planned out potential teething problems before proceeding with the project.

- Helped them secure funding from local authority

- By asking for clarification on plans and grant application, we helped them clarify and develop their plans 


\section{Case study 10 - Hackney Quest}

Summary of key aspects of progress

\begin{tabular}{|c|c|}
\hline May 1999 & - Applied for a place on Pedal Power \\
\hline May 1999 & $\begin{array}{ll}\text { - } & \text { Awarded Pedal Power place } \\
\text { - } & \text { Decided on idea for project - a cycle recycling project }\end{array}$ \\
\hline $\begin{array}{l}\text { June/July } \\
1999\end{array}$ & $\begin{array}{l}\text { - Requested and received donations of old cycles } \\
\text { - } \quad \text { Realised problems with storage and lack of maintenance } \\
\text { knowledge, and put brakes on project }\end{array}$ \\
\hline $\begin{array}{l}\text { October } \\
1999\end{array}$ & $\begin{array}{l}\text { - Unable to get backing and support, and go-ahead from } \\
\text { management committee } \\
\text { - Pedal Power offered to help find premises and mechanic }\end{array}$ \\
\hline $\begin{array}{l}\text { November } \\
1999\end{array}$ & $\begin{array}{l}\text { - Still unable to get management committee backing - did not } \\
\text { attend second course }\end{array}$ \\
\hline $\begin{array}{l}\text { November } \\
1999 \text { - }\end{array}$ & - Pedal Power involvement with project fizzled out \\
\hline
\end{tabular}

\section{Outcomes}

Although no project was set up, the following outcomes were achieved:

- Idea for project developed

- Initial enthusiasm for project generated

- Cycles donated

\section{Pedal Power's role}

- Seeing the Bike up your life literature led the worker involved to decide to have a go at setting up a cycle project. He had been thinking of it before and the opportunity to take part in Pedal Power led to him deciding to try it

- Help in deciding what sort of project to try and set up

- Information and advice

- Help in drawing up an action plan for the project and in tackling some of the problems they were facing, to try and make the project a reality, for example help and advice in getting a premises, and finding a cycle mechanic to get involved in the project

- We helped keep the idea alive for longer than it probably would have remained so if we had not still been in touch with the group (although we let it go in the end when continuing support might have helped).

\section{Case study 11 - Highfields Compact}

Summary of key aspects of progress

\begin{tabular}{|l|l|}
\hline & $\begin{array}{l}- \\
\text { Detached work with young people uncovers interest in } \\
\text { cycling activities }\end{array}$ \\
April 1999 & $\begin{array}{l}\text { Initial group of young people identified as interested in the } \\
\text { project }\end{array}$ \\
\hline
\end{tabular}




\begin{tabular}{|c|c|}
\hline & $\begin{array}{ll}\text { - } & \text { Trainee worker involved } \\
\text { - } & \text { Contact with local school and city council }\end{array}$ \\
\hline $\begin{array}{l}\text { April / } \\
\text { May } 1999\end{array}$ & $\begin{array}{l}\text { - Ran two cycle maintenance sessions } \\
\text { - Another trainee worker involved } \\
\text { - Pedal Power training course - } 1 \text { senior and } 2 \text { trainee workers } \\
\text { plus } 2 \text { young people } \\
\text { - Started work on an action plan for a cycle based fun day, and } \\
\text { continued with development work for their cycle } \\
\text { maintenance workshop }\end{array}$ \\
\hline $\begin{array}{l}\text { Spring / } \\
\text { Summer } \\
1999\end{array}$ & $\begin{array}{l}\text { - } \quad \text { Ran } 1 \text { more cycle maintenance session } \\
\text { - } \text { Organised and ran cycling based fun day }\end{array}$ \\
\hline $\begin{array}{l}\text { Summer/ } \\
\text { Autumn } \\
1999\end{array}$ & $\begin{array}{l}\text { - Trainee worker leading project leaves Highfields Compact } \\
\text { - Second trainee worker involved stops working on cycling } \\
\text { project } \\
\text { - Project stalls and is put on back burner }\end{array}$ \\
\hline $\begin{array}{l}\text { January } \\
2000\end{array}$ & $\begin{array}{l}\text { - } \quad \text { Attempt to resurrect project } \\
\text { - LSE Housing Cycling project worker agrees to help produce } \\
\text { project plan / proposal }\end{array}$ \\
\hline $\begin{array}{l}\text { February } \\
2000\end{array}$ & 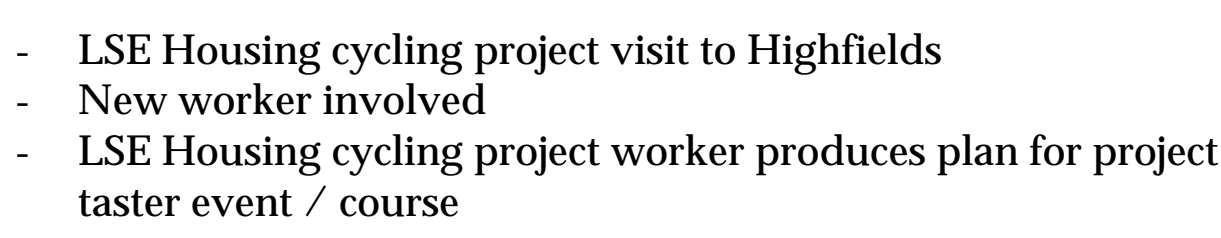 \\
\hline $\begin{array}{l}\text { August } \\
2000\end{array}$ & $\begin{array}{l}\text { - Project fizzled out with no further contact from Highfields } \\
\text { Compact }\end{array}$ \\
\hline
\end{tabular}

Outcomes

Although this work did not result in a cycling project, the following outcomes were achieved:

- Ran three cycle maintenance sessions for young people in the area

- Ran a cycling based fun day

- Two trainee workers received training in organisational skills, and experience in planning a project and running sessions and events

- Two young people received training and personal development through attending the training course and participating in planning the project and running events

- The idea for a cycling project was kept alive even after key workers left

\section{Pedal Power's role}

- Bringing them together with other groups working on similar things on the first training course

- Being part of the programme helped keep the idea of doing work around cycling alive, when their initial attempts stalled. 
- Help with planning for re-starting their project

- Providing them with information, contacts and help, for example we have been talked to Aylesbury college who run cycle maintenance training on behalf of the group

- Providing training for trainee workers and young people

Case study 12 - Recycle - a - cycle

Summary of key aspects of progress

\begin{tabular}{|c|c|}
\hline 1994 & - Cycle recycling project established by local residents \\
\hline 1997 & $\begin{array}{l}\text { - Became charity and secured National Lottery and local } \\
\text { authority funding }\end{array}$ \\
\hline 1998 & $\begin{array}{l}\text { - Project reopens after short closure with new premises and } \\
\text { employed staff } \\
\text { - Two of original people who set up project no longer involved }\end{array}$ \\
\hline Feb 1999 & - Full time co-ordinator employed \\
\hline April 1999 & - Co-ordinator applies and gets accepted onto Pedal Power \\
\hline $\begin{array}{l}\text { Spring } \\
1999\end{array}$ & $\begin{array}{l}\text { Co-ordinator having trouble winning trust of young people } \\
\text { and so the group does not attend first training course }\end{array}$ \\
\hline $\begin{array}{l}\text { Spring / } \\
\text { Summer } \\
1999\end{array}$ & $\begin{array}{l}\text { - Project crisis - administration and finances of project } \\
\text { mismanaged by full time co-ordinator, who is dismissed } \\
\text { - } \quad \text { Deficit in budget } \\
\text { - } \\
\text { - }\end{array}$ \\
\hline $\begin{array}{l}\text { Autumn } \\
1999\end{array}$ & $\begin{array}{l}\text { - Join Isle of Wight youth clubs' pool league to extend activities } \\
\text { - } \quad \text { LSE Housing cycling project worker visits project } \\
\text { - Project's treasurer trustee employed to work on project } \\
\text { administration }\end{array}$ \\
\hline $\begin{array}{l}\text { November } \\
1999\end{array}$ & $\begin{array}{l}\text { Two part-time co-ordinators and one young person attend } \\
\text { training course }\end{array}$ \\
\hline $\begin{array}{l}\text { December } \\
1999\end{array}$ & - Pedal Power small grant application submitted \\
\hline $\begin{array}{l}\text { December/ } \\
\text { January } \\
2000\end{array}$ & - Work on developing and clarifying grant application \\
\hline $\begin{array}{l}\text { February } \\
2000\end{array}$ & - Pedal Power small grant awarded \\
\hline March 2000 & - Project 'going from strength to strength' \\
\hline
\end{tabular}




\begin{tabular}{|l|ll|}
\hline & - & Numbers of young people involved necessitate more staff \\
& - & Working on further funding applications \\
Summer & - & Further crisis - Treasurer sacked - details not available \\
2000 & - & Consultant no longer involved as co-ordinator \\
\hline
\end{tabular}

\section{Outcomes}

- Two workers and one young person receiving training in practical and organisational skills

- Two workers receiving confidence building and personal development through attending training course

- Revised, successful, small grant application produced

- Project has persevered and developed through a difficult crisis, and received support through this time

- Further training for project staff

- Project receiving new safety equipment and cycle clothing

- Rent costs covered by small grant

- Action planning for fundraising stunt

\section{Pedal Power's impact}

- The project workers said that Pedal Power has helped raise their awareness of what's going on elsewhere

- Our ideas sheet and information on other projects has got them thinking about wider things they could be doing

- They said it was good to feel part of something bigger

- The project workers feel it is crucial that young people get the opportunity to get out of their immediate area to help them develop more confidence and self -esteem. One young person attended our second training course and so had the opportunity to travel and widen his perspective. We paid for this person to travel to the course, thus making his attendance possible

- Two of the workers involved came to the second training course. At first they had felt unable to come. When we visited them at their base we helped them realise it was a real possibility and helped enthuse them to come.

- The second training course gave them an opportunity to plan a fundraising stunt

- We awarded them with a small grant of $£ 2812$ in February 2000, towards tools, cycle safety equipment and clothing, rent of premises and staff training

- One of the project workers said that our support had helped their project move forward and develop very successfully. 


\section{Appendix 1 - Range of different types of project from the cycling projects database}

\begin{tabular}{|c|c|c|}
\hline Type of project & Brief explanation & $\begin{array}{l}\text { Number of } \\
\text { projects on } \\
\text { database }\end{array}$ \\
\hline Cycle recycling & $\begin{array}{l}\text { Project where old cycles are taken } \\
\text { in and worked on until they are } \\
\text { usable again. There are many } \\
\text { variations within this theme, for } \\
\text { example young people, } \\
\text { unemployed, skills training, bikes } \\
\text { sold, bikes given to participants. }\end{array}$ & 15 \\
\hline Cycling to work & $\begin{array}{l}\text { A project that promotes and } \\
\text { facilitates cycling to work for } \\
\text { employees, including: promotion, } \\
\text { cycle parking, shower and } \\
\text { changing provision, cycle } \\
\text { purchase vouchers, training, } \\
\text { Bicycle User Groups, information, } \\
\text { research and recommendations. }\end{array}$ & 6 \\
\hline Cycle promotion & $\begin{array}{l}\text { A project concerned with } \\
\text { promoting cycling, for example } \\
\text { through publicity, promotional } \\
\text { events, work with employers, } \\
\text { advice. }\end{array}$ & 6 \\
\hline $\begin{array}{l}\text { Cycling activities for } \\
\text { young people }\end{array}$ & & 6 \\
\hline Cycle parking & $\begin{array}{l}\text { A project concerned with } \\
\text { providing cycle parking facilities }\end{array}$ & 5 \\
\hline Cycle centre & $\begin{array}{l}\text { A centre providing facilities for } \\
\text { cyclists such as parking, showers, } \\
\text { repairs, cycle hire, cycle } \\
\text { promotion }\end{array}$ & 5 \\
\hline Cycle Pool & $\begin{array}{l}\text { A project providing a pool of } \\
\text { cycles, or cycle equipment, for } \\
\text { hire or lending out }\end{array}$ & 4 \\
\hline Cycling in schools & $\begin{array}{l}\text { A project aimed at promoting and } \\
\text { facilitating cycling to school, for } \\
\text { example by providing cycle } \\
\text { parking, promotion, teaching, }\end{array}$ & 4 \\
\hline
\end{tabular}




\begin{tabular}{|c|c|c|}
\hline & $\begin{array}{l}\text { training, on-road infrastructure } \\
\text { improvements }\end{array}$ & \\
\hline Transport integration & $\begin{array}{l}\text { A project researching and / or } \\
\text { facilitating the integration of } \\
\text { cycling with other forms of } \\
\text { transport for example buses, } \\
\text { trams }\end{array}$ & 4 \\
\hline Training & $\begin{array}{l}\text { Including training in cycling } \\
\text { safely, training in maintenance, } \\
\text { and training linked to } \\
\text { employment }\end{array}$ & 3 \\
\hline Cycle hire & & 2 \\
\hline Cycle taxi service & & 2 \\
\hline $\begin{array}{l}\text { BMX park or off-road } \\
\text { cycling track / route }\end{array}$ & & 2 \\
\hline $\begin{array}{l}\text { Build yourself a bike } \\
\text { scheme }\end{array}$ & $\begin{array}{l}\text { A project providing tools, space, } \\
\text { advice and old bikes for members } \\
\text { of the public to build themselves } \\
\text { up a working bike }\end{array}$ & 1 \\
\hline Cycle circus & $\begin{array}{l}\text { Circus and clown acts using cycle } \\
\text { props and touring by cycle }\end{array}$ & 1 \\
\hline Cycle delivery & $\begin{array}{l}\text { A project delivering parcels by } \\
\text { cycle }\end{array}$ & 1 \\
\hline $\begin{array}{l}\text { Cycling activities for } \\
\text { people with disabilities }\end{array}$ & $\begin{array}{l}\text { A project providing specialist } \\
\text { cycles to allow people with } \\
\text { disabilities to cycle }\end{array}$ & 1 \\
\hline $\begin{array}{l}\text { Donation of cycles to } \\
\text { homeless people }\end{array}$ & $\begin{array}{l}\text { A one-off donation of cycles to a } \\
\text { homeless persons charity. The } \\
\text { cycles being distributed to } \\
\text { homeless individuals or being } \\
\text { made available to homeless } \\
\text { people using hostels as pool bikes }\end{array}$ & 1 \\
\hline $\begin{array}{l}\text { Bicycle manufacture, } \\
\text { supply and hire }\end{array}$ & $\begin{array}{l}\text { A business manufacturing, } \\
\text { supplying, and renting out, } \\
\text { specialist cycles }\end{array}$ & 1 \\
\hline $\begin{array}{l}\text { Sponsored ride } \\
\text { organisation }\end{array}$ & $\begin{array}{l}\text { A project specialising in } \\
\text { organising and running } \\
\text { sponsored cycle rides }\end{array}$ & 1 \\
\hline
\end{tabular}




\begin{tabular}{|c|c|c|}
\hline $\begin{array}{l}\text { Supply of cycles and } \\
\text { maintenance training to } \\
\text { Southern countries }\end{array}$ & $\begin{array}{l}\text { A project that sends old cycles } \\
\text { from the UK to poor Southern } \\
\text { countries, where they are fixed } \\
\text { and maintained with associated } \\
\text { training for people in the } \\
\text { recipient countries }\end{array}$ & 1 \\
\hline $\begin{array}{l}\text { Advertising using cycles } \\
\text { and specialist cycle } \\
\text { trailers }\end{array}$ & $\begin{array}{l}\text { A business that uses cycles and } \\
\text { specially designed cycle trailers } \\
\text { for advertising and promotional } \\
\text { events }\end{array}$ & 1 \\
\hline Total & & 73 \\
\hline
\end{tabular}




\section{Appendix 2 - Detailed example of the Basic support provided to one group}

\begin{tabular}{|c|c|}
\hline What the group requested & What support we provided \\
\hline $\begin{array}{l}\text { Information on other } \\
\text { projects already running }\end{array}$ & $\begin{array}{l}\text { - An index for the cycling projects } \\
\text { database, together with a request form } \\
\text { so they could request more detailed } \\
\text { information about any of the projects } \\
\text { they were interested in } \\
\text { - } \begin{array}{l}\text { Detailed information from the database } \\
\text { on cycle recycling projects }\end{array}\end{array}$ \\
\hline $\begin{array}{l}\text { - Advice, including costs, } \\
\text { insurance, suppliers }\end{array}$ & $\begin{array}{l}\text { - Our insurance information sheet } \\
\text { - Our cycling organisations information } \\
\text { sheet - to provide contacts for } \\
\text { organisation that could help with more } \\
\text { information } \\
\text { - Specific written advice about how to } \\
\text { find information on costs and suppliers }\end{array}$ \\
\hline $\begin{array}{l}\text { Ideas - how to start up and } \\
\text { get spares }\end{array}$ & $\begin{array}{l}\text { - We suggested that they contact existing } \\
\text { projects (that we had provided contact } \\
\text { details for) in order to get advice and } \\
\text { ideas } \\
\text { - Our ideas sheet }\end{array}$ \\
\hline $\begin{array}{l}\text { - Technical information - } \\
\text { including cycle books, road } \\
\text { safety, repairs }\end{array}$ & $\begin{array}{l}\text { - Our training and accreditation } \\
\text { information sheet - this has some } \\
\text { information about safe road cycling } \\
\text { training, and contacts for getting more } \\
\text { information } \\
\text { - We provided details about a dedicated } \\
\text { bookshop selling books on all aspects of } \\
\text { cycling, and recommended a specific } \\
\text { book for information on repairs }\end{array}$ \\
\hline \multicolumn{2}{|c|}{$\begin{array}{l}\text { In addition to these specific responses we also: } \\
\text { - } \quad \text { Provided a full list of our information sheets in case there were any others } \\
\text { they would like to see } \\
\text { - } \quad \text { Provided a template cycling questionnaire for the group to use in } \\
\text { collecting information from their users } \\
\text { - } \quad \text { Offered that they should get in touch if they had wanted any more help or } \\
\text { information } \\
\text { - } \quad \text { asked them to let us know how they were getting on }\end{array}$} \\
\hline
\end{tabular}




\section{Appendix 3 - Promotion and advertising}

We put out adverts about Bike up your life in a number of youth, cycling and community development newsletters / publications. Pieces were included in:

- the March 1999 newsletter of the Development Trusts Association

- the March 1999 newsletter of London Youth Matters

- the April 1999 'Young People Now' - which is the monthly National Youth Agency magazine

- the Foyer Foundation Bulletin going out 16/04/99

- the Quest Trust's newsletter 'Grassroots'

- the Streets for People newsletter April 1999

- Cyclists Touring Club magazine - May/June edition

- the London Cycling Club's 'London Cyclist'

- the April Tenant Participation Advisory Service (TPAS) newsletter

- the April newsletter of the National Association of Councils for Voluntary Services (NACVS)

- the May newsletter of the Cycling Project for the North West

- Transport 2000 newsletter 19/04/99

In addition to these publications, we also sent out some direct publicity material through the following networks:

- Crime Concern accepted a Flyer and information about the programme and distributed copies to their local projects

- Youth Clubs UK took flyers to a conference on Youth Achievement Awards and working with disaffected youths, $10^{\text {th }}$ to $11^{\text {th }}$ April 1999.

- The Priority Estates Project offices in London and Manchester accepted Flyers

- We mailed Flyers to the Principal Youth Officers for each Local Authority in England

- We sent Flyers to groups from our cycling projects database 


\section{Appendix 4 - Data collection and recording}

Table showing how data was collected and recorded throughout the work

\begin{tabular}{|c|c|}
\hline $\begin{array}{l}\text { Process / Data } \\
\text { source }\end{array}$ & How the data was collected and recorded \\
\hline $\begin{array}{l}\text { Database of } \\
\text { established } \\
\text { national cycling } \\
\text { projects }\end{array}$ & $\begin{array}{l}\text { We identified projects initially through the DETR Cycle Challenge programme (a programme of grant giving for } \\
\text { cycling projects that supported approximately } 60 \text { projects). We contacted these and any other individual projects } \\
\text { we had heard of by telephone or post and collected information from them through a postal/written } \\
\text { questionnaire. We also asked each project we contacted about any other projects they knew about, and generally } \\
\text { continued to gather information about new projects throughout our work. Any new projects that we found out } \\
\text { about we sent questionnaires to. The information we collected was entered into fields in an Access database. The } \\
\text { information was updated and added to through a second postal/written questionnaire }\end{array}$ \\
\hline $\begin{array}{l}\text { Investigation of } \\
\text { potential for } \\
\text { establishing pilot } \\
\text { projects }\end{array}$ & $\begin{array}{l}\text { We in initially spoke on the telephone to local authority cycling or sustainable transport officers from almost all } \\
\text { London Boroughs, and representatives from a number of the borough branches of the London Cycling } \\
\text { Campaign. The conversations were conducted around a basic set of questions. The information collected from } \\
\text { these conversations was recorded as written notes. } \\
\text { - In the most promising boroughs we followed these initial conversations up with further discussion with cycling } \\
\text { officers and LCC representatives, and other relevant people. This information was again recorded in written } \\
\text { notes. We collected some additional relevant material where relevant for example existing reports, leaflets, etc. }\end{array}$ \\
\hline $\begin{array}{l}\text { Developing and } \\
\text { the } 4 \text { live pilot } \\
\text { projects }\end{array}$ & $\begin{array}{l}\text { - Information was gathered and recorded through this process in a variety of ways. Chiefly: } \\
\text { - Negotiations and discussions recorded in written notes and letters } \\
\text { - Ultimately most aspects were recorded in the individual project proposals } \\
\text { - } \quad \text { The process of negotiation and setting up was recorded as written discussion notes and reports }\end{array}$ \\
\hline $\begin{array}{l}\text { Setting up the } 4 \\
\text { pilot projects }\end{array}$ & $\begin{array}{l}\text { - For the } 2 \text { projects that we have had close involvement with information about this process has been recorded } \\
\text { through letters, written discussion and reports. It has then been written up as case studies. } \\
\text { - For the other } 2 \text { projects, we have gathered information on this process through interviews with the } \\
\text { organisation(s) involved in setting them up, and recorded this as written notes. The information has then been } \\
\text { written up as case studies. }\end{array}$ \\
\hline
\end{tabular}




\begin{tabular}{|c|c|}
\hline $\begin{array}{l}\text { Outcomes from } \\
\text { the } 4 \text { pilot } \\
\text { projects }\end{array}$ & $\begin{array}{l}\text { Monitoring of progress, outputs and outcomes was part of the integral work involved in the projects. Data and } \\
\text { information has been collected through written records (of numbers of users etc.) kept by the people running the } \\
\text { projects on the ground. Feedback from users has been recorded. We have gathered further information from } \\
\text { people running the projects through discussion and informal interviews, recorded as written notes. All of this } \\
\text { information has been written up in project case studies. }\end{array}$ \\
\hline $\begin{array}{l}\text { Bike up your life } \\
\text { support } \\
\text { programme }\end{array}$ & $\begin{array}{l}\text { This programme has involved a variety of levels of support to groups and has been monitored on a number of } \\
\text { different levels: } \\
\text { - Interest in the programme (enquiries) has been recorded in a 'mailing list' database } \\
\text { - We have gathered information on groups that made an initial enquiry to Bike up your life but then didn't } \\
\text { apply to us for support, through telephone questionnaires }\end{array}$ \\
\hline $\begin{array}{ll}\text { - } & \text { Basic } \\
& \text { support }\end{array}$ & $\begin{array}{l}\text { - Information about the groups receiving support was gathered through their application forms and recorded } \\
\text { in fields of an Access database } \\
\text { - Information on support requested by groups was gathered through a written questionnaire and recorded in } \\
\text { the database } \\
\text { - Information on what support was given to groups has been recorded in the database } \\
\text { - Feedback from groups has been gathered through written and telephone questionnaires, and in depth } \\
\text { interviews, and recorded as written notes and summarised results } \\
\text { - Information on the outcomes of the groups' activities have been gathered through written and telephone } \\
\text { questionnaires }\end{array}$ \\
\hline $\begin{array}{l}\text { - Pedal } \\
\text { Power }\end{array}$ & $\begin{array}{l}\text { - The same information has been recorded as for the Basic support groups, Plus: } \\
\text { - Information on support given, the process the groups have gone through in setting up projects, their } \\
\text { backgrounds, and the results they have achieved has been gathered through in depth interviews and } \\
\text { ongoing informal contact. This has been recorded as written notes and case study write-ups. } \\
\text { - Information on the training courses that groups attended was recorded through written questionnaires }\end{array}$ \\
\hline
\end{tabular}




\title{
Appendix 5-Obtaining full copies of the cycling database
}

Copies of the cycling projects database produced as part of this work are available electronically, or in hard copy from:

\author{
Jake Elster \\ CASE \\ London School of Economics \\ Houghton Street \\ London WC2A 2AE
}

or Jo Bell

Cycling Project for the North West

1 Enterprise Park

Agecroft Road

Pendlebury

Manchester M27 8WA 